OPEN ACCESS

Edited by:

Bhaskar Singh,

Central University of Jharkhand, India

Reviewed by:

Smriti Shrivastava,

Amity University, India

Abu Yousuf,

Shahjalal University of Science and

Technology, Bangladesh

*Correspondence:

Adewale Adewuyi

walexy62@yahoo.com

Specialty section:

This article was submitted to

Bioenergy and Biofuels,

a section of the journal

Frontiers in Energy Research

Received: 14 July 2021 Accepted: 31 January 2022

Published: 17 February 2022

Citation:

Adewuyi A (2022) Underutilized Lignocellulosic Waste as Sources of Feedstock for Biofuel Production in

Developing Countries.

Front. Energy Res. 10:741570. doi: 10.3389/fenrg.2022.741570

\section{Underutilized Lignocellulosic Waste as Sources of Feedstock for Biofuel Production in Developing Countries}

\author{
Adewale Adewuyi * \\ Department of Chemical Sciences, Faculty of Natural Sciences, Redeemer's University, Ede, Nigeria
}

The need for a reliable and sustainable energy source, stability in energy price and solution to environmental challenges of fossil fuel has led to searching for an alternative energy source to fossil fuel. Several alternative sources have been developed over time, but they are limited in one form or another. However, biofuel such as bioethanol has been identified as a superb alternative with superior properties to fossil fuel. One major challenge with biofuel is the high production cost resulting from feedstock, which may also serve as a food source. In order to address this challenge, research is focused on searching for cheap and sustainable feedstock for biofuel production. Currently, attention is on lignocellulosic waste as feedstock with a keen interest in developing the most appropriate technique for processing it to bioethanol, especially in developing countries, which is the focus of this review. This review involves converting lignocellulosic waste to bioethanol and the pretreatment steps involved as well as its challenges, prospect and economic aspect. Among the pretreatment steps reported, biological treatment remains outstanding but with a few challenges which can be managed. Biofuel has come to stay in developing countries with lots of opportunities that favours its production cost. Although the high cost of enzyme production has been identified as a challenge to the economic viability of lignocellulosic bioethanol, there is hope that developing an efficient bio-system for simultaneous saccharification and fermentation (SSF) and consolidated biomass processing may help circumvent the challenge. In conclusion, the effective utilization of lignocellulosic waste in an efficient biocatalyst system can serve as an economically viable means to overcome the challenge posed by fossil fuel.

Keywords: Saccharomyces cerevisiae, saccharification, lignocellulosic waste, biofuel, bioethanol

\section{INTRODUCTION}

Lignocellulosic materials are biomass capable of serving as a viable resource for renewable bioenergy. They are of plant biomass and in large quantity on earth. They include agricultural, forestry or wood wastes, which mainly contains cellulose, lignin, tannin, saponin and hemicellulose. Cellulose makes up the entire polysaccharide structure of plant cell wall corresponding to about 30-50\% dry weight of lignocellulose (Harris and DeBolt, 2010), containing a linear chain of $\beta(1 \rightarrow 4)$ linked D-glucose units. The cellulose may be degraded by enzyme cellulase to glucose which is finally converted to biofuel. Unlike cellulose, hemicellulose contains many heteropolymers such as glucomannan, glucuronoxylan, xyloglucan, xylan and arabinoxylan (Scheller and Ulvskov, 2010), giving it a random amorphous structure. It may be hydrolyzed to simple sugar by acid or base hydrolysis 


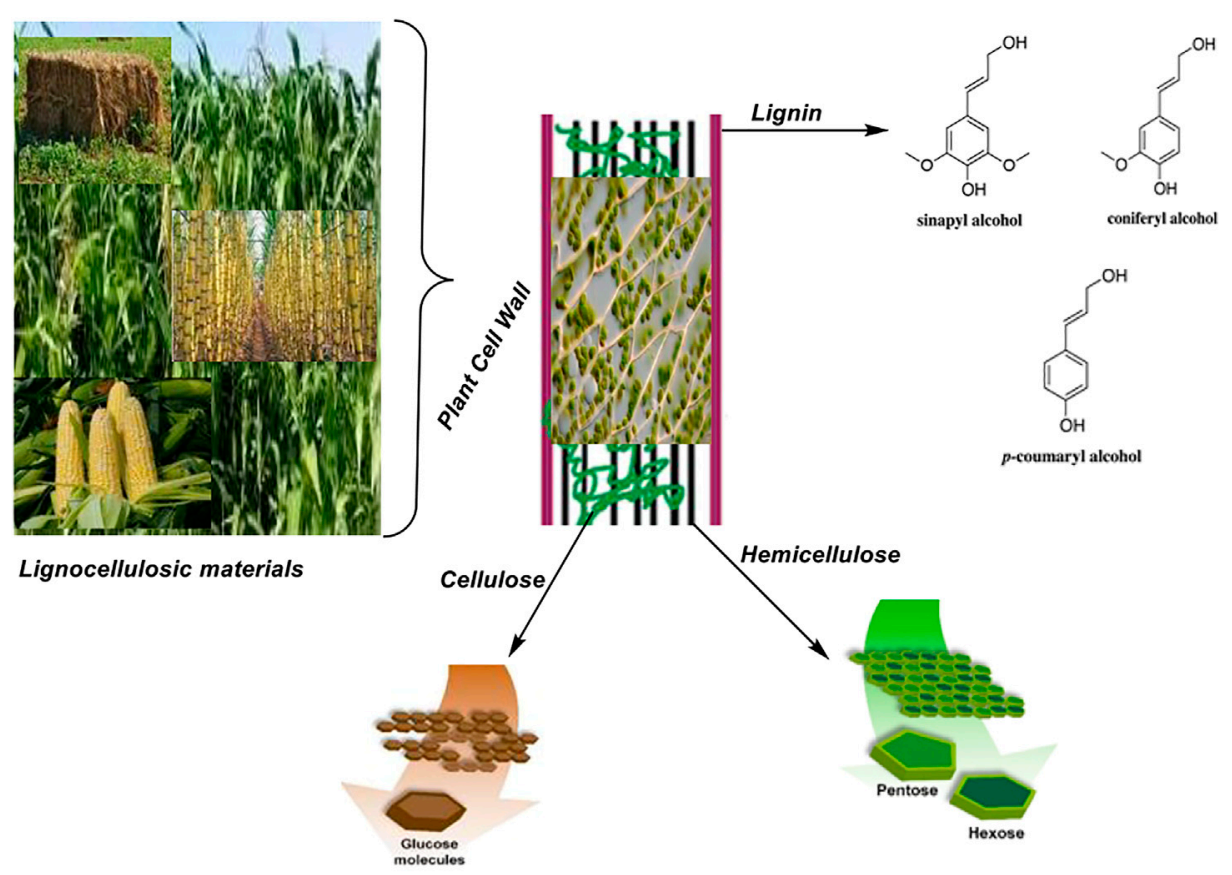

FIGURE 1 | Essential components and structure of lignocellulose.

or by the action of enzyme hemicellulase. Simple sugar may serve as a source of biofuel. Authors (Scheller and Ulvskov, 2010) have reported lignin as the second most abundant carbon source after cellulose. It is different from cellulose and hemicellulose because it is a non-carbohydrate aromatic heteropolymer that may be obtained from three different building blocks, including coniferyl alcohol (G), p-coumaryl alcohol (H), and sinapyl alcohol (S) as shown in Figure 1. It is necessary to remove lignin during biofuel production since it does not have a carbohydrate base structure that can contribute simple sugar as a monomeric base for biofuel production. Plant-sourced biomass such as lignocellulosic materials is an important feedstock for many biotechnological processes and a sure sustainable and renewable source of energy for now and the future. A study (Kumar et al., 2008) revealed the capacity of a process plant to produce up to $1.3 \times 10^{10}$ metric tons of biomass (on a dry weight basis) annually via photosynthetic fixation of $\mathrm{CO}_{2}$ in the presence of sunlight. The study further revealed that such biomass possesses equivalent energy of about two-thirds of the world's energy requirement. This showcased lignocellulosic materials, an example of plant-sourced biomass as a potential sustainable energy source for the present and future needs.

The use of lignocellulosic materials as feedstock for bioethanol production as an alternative fuel to fossil fuel is an essential means of circumventing fossil fuel challenges. The conversion of lignocellulosic materials may be achieved in three steps: removal of lignin to have access to cellulose and hemicellulose, hydrolysis of the carbohydrate polymers to obtain free sugars and fermentation of the free sugar to bioethanol. A large quantity of lignocellulosic waste generated annually from agricultural and food processing industries can serve as feedstock for biofuel production. The use of these wastes from agricultural and food processing industries can help reduce the cost of producing biofuel as well as maintain a clean environment. Other materials like grasses, forest waste and municipal solid wastes are also cheap, abundant renewable resources that may serve as feedstock. The use of lignocellulosic materials for biofuel production can help reduce greenhouse gases emission, which may help mitigate global warming (Jeswani et al., 2020). Presently, research is focused on improving or developing adequate technology that can efficiently convert lignocellulosic waste to biofuel with very minimal production cost. The use of lignocellulosic waste is one way to avoid competition between the use of agricultural proceeds as food or biofuel. As previously reported (Elumalai et al., 2018), furfural, 5hydroxymethylfurfural, and levulinic acid are examples of potential chemicals obtained from lignocellulose conversion that may serve as a precursor for fuel or building blocks for other valuable products.

The use of lignocellulose as a source of biofuel may suffer from a few challenges; this may include the difficulty associated with finding and sustaining a cost-effective technology for cellulose conversion and sugar extraction processes. Achieving this requires specific pretreatment steps due to the bio-component of lignocellulose substrate, which needs to be taken care of. Such pretreatment may end up increasing the production cost. Apart from this, the use of various chemicals in lignocellulose pretreatment generates chemical wastes or inhibitory compounds, which may negatively affect the performance of the hydrolysis and fermentation processes. Moreover, distinct removal of the chemical wastes or inhibitory compounds from the pretreatment stage further increases production cost as this 
TABLE 1 | Composition of selected lignocellulosic materials.

\begin{tabular}{|c|c|c|c|c|}
\hline Biomass & Cellulose (\%) & Hemicellulose (\%) & Lignin (\%) & References \\
\hline Grasses & $25-40$ & $25-50$ & $10-30$ & (Stewart et al., 1997), (Hon et al., 2000) \\
\hline Cotton stalk & 31 & 11 & 30 & Rubio et al. (1998) \\
\hline Bamboo & $49-50$ & $18-20$ & 23 & (Reguant and Rinaudo, 2000), (Alves et al., 2010) \\
\hline Wheat straw & $35-39$ & $22-30$ & $12-16$ & (Prasad et al., 2007), (Grohmann et al., 1986) \\
\hline Sugarcane tops & 35 & 32 & 14 & Jeon et al. (2010) \\
\hline Tall fescue straw & 31 & 20 & 14 & Kumar and Murthy, (2011) \\
\hline Douglas fir & 44 & 11 & 27 & Isikgor and Becer, (2015) \\
\hline Switchgrass & $35-40$ & $25-30$ & $15-20$ & Howard et al. (2003) \\
\hline Nut shell & $25-30$ & $22-28$ & $30-40$ & Sinner et al. (1979) \\
\hline Jute fibre & $45-53$ & $18-21$ & $21-26$ & Mosihuzzaman et al. (1982) \\
\hline Elephant grass & $38-40$ & $18-24$ & 25 & De Vrije et al. (2002), Sørensen et al. (2008) \\
\hline Hardwood & $40-55$ & $20-40$ & $18-25$ & Betts et al. (1991), McKendry, (2002) \\
\hline Rice hulls & $28-38$ & 17 & $16-22$ & Guo and Rockstraw, (2007), Rabemanolontsoa and Saka, (2013) \\
\hline
\end{tabular}

may even affect the quality of biofuel produced. In order to avoid the challenges that come with the use of chemical pretreatment, enzymatic pretreatment of lignocellulose is considered to be more efficient with less chemical waste. Although the use of enzymatic pretreatment is selective, precise, and environmentally friendly, it is expensive with a high cost to sustain, which poses a challenge in poor developing countries as these countries lack the financial capacity to sustain or maintain the technology. The enzymes are temperature sensitive, and the process conditions will have to be carefully maintained. Different strains of microorganisms have been studied for their capacity and novelty to function as viable sources of lignocellulolytic enzymes. A previous study (Druzhinina et al., 2012) reviewed the three species of Trichoderma, namely Trichoderma atroviride, Trichodermareesei, and Trichoderma virens, as sources of carbohydrate-active enzymes. Large number of lignocellulosic wastes are generated yearly in developing countries. Moreover, these lignocellulosic wastes are inappropriately disposed creating a waste disposal challenge. Therefore, it is important to identify the possible use of these waste by converting them to useful products making it a win-win situation more like waste-towealth. However, some of these wastes have been identified but some of them are still underutilized. Therefore, this study aimed to consider the prospect of underutilized lignocellulosic wastes generated in developing countries as possible sources of feedstock for biofuel production, focusing on bioethanol with keen interest on evaluating the different pretreatment steps and process modifications necessary for obtaining better bioethanol production.

\section{Composition and Structure of Lignocellulose Biomass}

The main compositions of lignocellulose are cellulose (20-50\%), hemicellulose (15-35\%) and lignin (5-30\%) as previously reported (Lynd et al., 2002; Chen, 2014; Michelin et al., 2015); this comes along with other molecular compounds which are organized in complex structures as shown in Figure 1. The cellulose, hemicellulose and lignin composition of some selected lignocellulosic materials are summarized as presented in Table 1. Despite the potential exhibited by lignocellulosic materials, they express resistance to degradation due to the hydrophobicity of lignin, the lignin-hemicellulose matrix encapsulation and the crystallinity of cellulose (Isikgor and Becer, 2015). Cellulose is the main component of interest in lignocellulose for the production of biofuel. It is a polymer containing d-anhydro-glucopyranose units linked together by $\beta-1,4$ linkages; with number of glucose molecules in a chain varying from 100 to 1,000 depending on the source of the lignocellulose and this has a key role to play in the yield of biofuel because the higher the number of glucose molecule per chain length the higher the biofuel conversion yield would be expected to be. Cellulose contains hydroxyl groups that promote inter and intramolecular hydrogen bonding resulting in crystalline structure (with some level of amorphous structure) of cellulose, which reduces its solubility in water and resistance to hydrolysis that poses resistance to ease of conversion to glucose units and finally, bioethanol. Hemicellulose, on the other hand, is heterogeneous, containing sugars and uronic acids. It is amorphous, short-chained and capable of joining lignin and cellulose together (Chundawat et al., 2010). It contains several heteropolymers such as, glucomannan, galactomannan, xylan, glucuronoxylan, xyloglucan, and arabinoxylan (Isikgor and Becer, 2015); the composition of hemicelluloses varies depending on the source of the lignocellulose. Lignin remains the most complex component of lignocellulose, which is amorphous and capable of forming a three-dimensional and irregular network when complexed with cellulose and hemicellulose; this complex provides structural stability for the lignocellulose. As shown in Table 1, the distribution of cellulose, hemicellulose and lignin from a single source is not uniform.

\section{Lignocellulosic Waste as Sources of Feedstock}

A large number of wastes are annually generated in developing countries. Most of the wastes are of an environmental challenge as they constitute a nuisance in the environment when disposed of inappropriately; waste disposal is a major problem in poor developing countries. It is important to find practical applications for these wastes. Lignocellulosic wastes are one of the main groups of wastes suitable for the production of biofuel. 
Sources of lignocellulosic waste may be classified as waste generated from forestry resources, agricultural resources, and by-products of agricultural-based industry. The waste from forestry resources is generated from forest cutting, reforestation, forest processing, forest protection, etc., while waste generated from agricultural resources include crop straws, agricultural crops, by-products from crop harvest, etc. An essential way of using these lignocellulosic wastes is in their conversion to biofuel, majorly bioethanol production, where they supplement and replace nonrenewable sources of energy. The lignocellulosic wastes are the most abundant waste in developing countries with significant cellulose and hemicellulose content, requiring pretreatment steps before conversion to biofuel. The use of lignocellulosic wastes as a renewable source of biofuel depends on developing an economically viable process technique (Kricka et al., 2015). The process requires the use of cellulase to hydrolyze the $\beta$-1,4-glucosidic linkages of cellulose to low molecular weight sugar that can be converted to bioethanol.

\section{Agro-Based Wastes as Lignocellulosic Materials for Biofuel Production}

Several agricultural wastes have been screened for their potential use as sources of biofuel. Biofuel production using agricultural or industrial wastes containing lignocellulosic material is of great interest because it minimizes the human 'food versus fuel' dilemma encountered with the substrates of the firstgeneration biofuel (Clauser et al., 2021; Malode et al., 2021). Lignocellulosic wastes are considered to be second-generation feedstock. Examples include bagasse wastes, rice wastes, corn wastes, spent grains and miscellaneous wastes.

Bagasse waste is a by-product of the sugar industry; it is a dry pulpy fibrous material left after crushing sorghum or sugarcane stalks. Apart from its high moisture content, the composition is similar to that of wood. The dry weight contains cellulose, lignin, and hemicellulose, etc. It has found application in biofuel production due to the hydrolysis of its hemicellulose and cellulose (Bezerra and Ragauskas, 2016). Sugarcane bagasse has played an essential role in bioethanol production. Developing countries like Brazil, where the sugarcane industry plays a crucial role in power generation, receive incentives from the government to support energy production. Molasses containing sugar have been fermented for bioethanol production as previously reported (Bhatnagar et al., 2016), other studies (Merschmann et al., 2016; Barbosa et al., 2017; Carminati et al., 2019) have revealed the use of sugarcane bagasse in bioethanol production.

Cashew apple bagasse is the by-product obtained from the cashew apple juice industry. It is a lignocellulosic waste material that is underutilized globally without a specific use in most developing countries. It is considered as waste, and about $15 \%$ $(\mathrm{w} / \mathrm{w})$ of cashew apple bagasse produced during juice production are discarded as waste (de Souza Bezerra et al., 2015); finding application for this waste is essential as the lignocellulose content suggests the potential of being a good source for biofuel production. Brazil, a developing country, accounts for $11 \%$ of the world cashew nut production, which represents over five million tons of cashew production (dos Santos Lima et al., 2012); with the large volume of waste produced, cashew agroindustry can serve as an outstanding source of raw material for biofuel production. To achieve the best use of cashew apple bagasse, pretreatment methods have been developed, such as the use of dilute sulphuric acid (Rocha et al., 2014), sodium hydroxide (Rodrigues et al., 2011) and alkaline hydrogen peroxide (da Costa et al., 2015).

Rice wastes are mainly rice straw and husk. They are currently receiving close attention as an alternative source of energy due to their cellulose and hemicellulose contents. They have been reported to contain a high amount of cellulose and hemicellulose (Ibitoyea et al., 2020; Tufail et al., 2021). Over 120 million tons of rice husks are produced annually as waste. One primary application of rice husk is biofuel production (Hossain et al., 2018); this is the situation in a country like India, where large rice production occurs annually. Studies have shown that subjecting rice husk to the appropriate method can generate sufficient power to help power communities in a country like India and China, where rice is produced in substantial quantities annually (Pradhan et al., 2013). However, rice husk has been reported to be poorly saccharified due to its high levels of lignin. It produces high fermentation chemical inhibitors, which indicates the need for a better treatment procedure (Wood et al., 2016; Khaleghian et al., 2017). Compared to other lignocellulosic cereals, rice husk and straw contain high levels of silica in their cell walls, with rice husk having the highest (Wu et al., 2018; Chun and Lee, 2020). An estimation of four million tons of rice straw is produced in Egypt annually and globally, producing about 205 billion liters of bioethanol annually (Belal, 2013). It contains lignin (5-24\%), cellulose 32-47\%, ashes (18.8\%) and hemicelluloses (19-27\%), as previously reported (Belal, 2013). Bioethanol production from rice straw by saccharification and fermentation with optimized cellulase cocktail and fermenting fungus has been reported (Takano and Hoshino, 2018). A study reported bioethanol production from a mixture of rice hull and orange peel wastes (Taghizadeh-Alisaraei et al., 2019); the study revealed a bioethanol yield of $0.295 \mathrm{~L} \mathrm{~kg}^{-1}$ from dry rice hull and orange peel. Rice bran is also an essential source of feedstock for biofuel production; an estimated annual world production is about 76 million tons (Kahlon, 2009). It contains about 34-52\% carbohydrate (Webb, 1991), which suggests it is a primary source of glucose for bioethanol production. Production of bioethanol from rice bran using Bacillus cereus strain McR-3 has been reported (Tiwari et al., 2015).

Corn is an integral part of food in most developing countries. With about a $44.74 \%$ increase in corn production in 2001-2011 (Zhang et al., 2012), the generation of corn waste such as corn husk and corn stover increased. The cobs, leaves and stalks left after the harvest of corn are referred to as stover. It is abundantly available, and it is considered as waste since there is no specific use for it presently. Bioethanol production was reported from corn cobs via a combined thermochemical and fermentative processes (Luque et al., 2016). Corn cobs have been reported to be a better source of glucose than stalks and leaves (Chun and Lee, 2020). A study (Akinola and Erkurt, 2014) using wastewater containing cornstalk for bioethanol production was reported to have desirable output on reducing sugar yield. The study further 
TABLE 2 | Selected biofuel producing companies, feedstock and location.

\begin{tabular}{|c|c|c|}
\hline Company & Location & Feedstock \\
\hline Global biofuels & Nigeria & Sweet sorghum \\
\hline Caltech Ventures & Ghana & Cassava \\
\hline China Resources Alcohol Corporation & China & Corn stover \\
\hline ACABIO Coop. Lta & Argentina & $\begin{array}{l}\text { Corn and grain } \\
\text { sorghum }\end{array}$ \\
\hline ANDRITZ Feed and Biofuel & Chile & Biomass \\
\hline Miranda & Russia & Wheat \\
\hline ETIP Bioenergy & Brazil & Sugarcane \\
\hline $\begin{array}{l}\text { Zagros Green Fuel development } \\
\text { Company }\end{array}$ & Iran & Sugarcane \\
\hline Mabele Fuels Pty (Ltd.) & South Africa & Sorghum \\
\hline Bioenergy & South Africa & Distillers grain \\
\hline
\end{tabular}

identified the pretreatment method of three-stage alkaline-acidenzymes as the rate-limiting step for bioethanol production. An optimum yield for reducing sugar was reported to be $604.96 \mathrm{mg}$ $\mathrm{g}^{-1}$ cornstalk. Cornstalk juice has also been reported in bioethanol production using Saccharomyces cerevisiae (Bautista et al., 2019).

Spent grain from the brewery industry contains lignocellulose (Patel et al., 2018) that may be useful in biofuel production. It is the most abundant by-product emanating from the brewing industry (Kavalopoulos et al., 2021). The composition of brewery spent grain varies according to the process it is subjected to and the type of additive added to the production process. However, it contains mainly cellulose and hemicellulose. A study (Xiros and Christakopoulos, 2009) reported enhancing bioethanol production from brewer's spent grain using Fusarium oxysporum. The influence of temperature and phosphoric acid concentration on brewer's spent grain treatment in preparation for bioethanol production has been reported (Rojas-Chamorro et al., 2018). The study revealed that phosphoric acid as a pretreatment agent enhanced sugar production and subsequently good yield of ethanol. It has become evident that brewer's spent grain is a feedstock for producing an easily hydrolysable simple sugar for the production of bioethanol. The main parameters and mechanism of drying kinetics of brewer's spent grain with the capacity to produce biodiesel were reported (Mallen and Najdanovic-Visak, 2018); the authors used acid catalyst in the transesterification. The study revealed a new approach towards the volarisation of brewer's spent grain. A previous study reported bioethanol production from brewer's spent grains using consolidated bioprocessing (Wilkinson et al., 2017). The process recognized Aspergillus oryzae and Saccharomyces cerevisiae NCYC479 as outstanding fungi that gave the highest ethanol yield, indicating that 1 ton of brewer's spent grain yields $94 \mathrm{~kg}$ of ethanol.

Agro-industrial residues are examples of lignocellulosic materials; different types of miscellaneous agro-industrial residues have been tested for their potentials as feedstock for biofuel. They are majorly solid wastes referred to as secondgeneration feedstocks for biofuel and are primarily composed of polysaccharides (Nissilä et al., 2014; Gottumukkala et al., 2016; Sadh et al., 2018). Agriculturally based industries produce a large volume of wastes every day that can be of immense benefit. If these wastes are released directly into the environment without being treated, they may become pollutants. They are underutilized; therefore, it is vital to find a way of making the best use of them. They may be sugarcane bagasse, cassava peel, groundnut oil cake, coconut oil cake, stem-bark, fruit peels, sawdust and vegetable leftovers. Sludge generated from pulp and paper industries may also fall into this category. They are rich in cellulose fibers. Most indigenous local industries in developing countries produce large volumes of waste that may find useful applications in biofuel production. With the provision of appropriate technology, making use of these wastes will generate energy and provide employment that will help reduce the poverty rate. Some selected biofuel companies in developing countries are shown in Table 2. Lignocellulosic waste remains cheap source of feedstock for biofuel production, however, they are challenged with their recalcitrant content like the presence of lignin which needs to be removed. Therefore, necessitating the need for a pretreatment of the waste before conversion to biofuel. It is important to select the most appropriate pretreatment to avoid production of side products that may interfere or detrimental to the growth of the microorganism involved in the bioprocessing of lignocellulosic material to biofuel.

\section{Treatment of Lignocellulosic Materials for Biofuel Production}

Treatment of lignocellulosic materials is vital in preparedness for biofuel production. This pretreatment stage is the most energyintensive and expensive stage in the convention of lignocellulosic materials to biofuel (Ab Rasid et al., 2021). The pretreatment of lignocellulosic materials may result in physical or chemical changes causing changes in particle size and porosity to enhance penetration of solvent and catalyst. Such treatment may affect cellulose crystallinity, linkage among lignin, cellulose and hemicellulose, and the degree of polymerization. Treatment cost is one of the significant factors that determine the type of treatment used; moreover, the nature of chemical reagent and lignocellulose material plays an important role as well in determining the treatment to use. In order to minimize the challenges from chemical side products, the current production of bioethanol considers the use of biological treatment, which is a three-step process involving pretreatment of lignocellulose feedstock, hydrolysis of sugar polymer such as cellulose and hemicellulose and fermentation of sugar; this is described in Figure 2. During pretreatment, the aim is to separate lignocellulose into its major components, cellulose, hemicellulose, and lignin to achieve conversion to biofuel easily. Single-step pretreatment such as pyrolysis may not be efficient due to the numerous molecules present in lignocellulosic materials. The pretreatment step will require more than one step in most cases. The pretreatment methods may be categorized as; physical, chemical, mechanical and biological treatments; however, the various methods may be combined (Barakat et al., 2013) to achieve high efficiency. Previously reported methods include hydrolysis, solubility, steam explosion, ammonia fiber explosion (AFEX), and fractionation in order to separate cellulose, hemicellulose and 


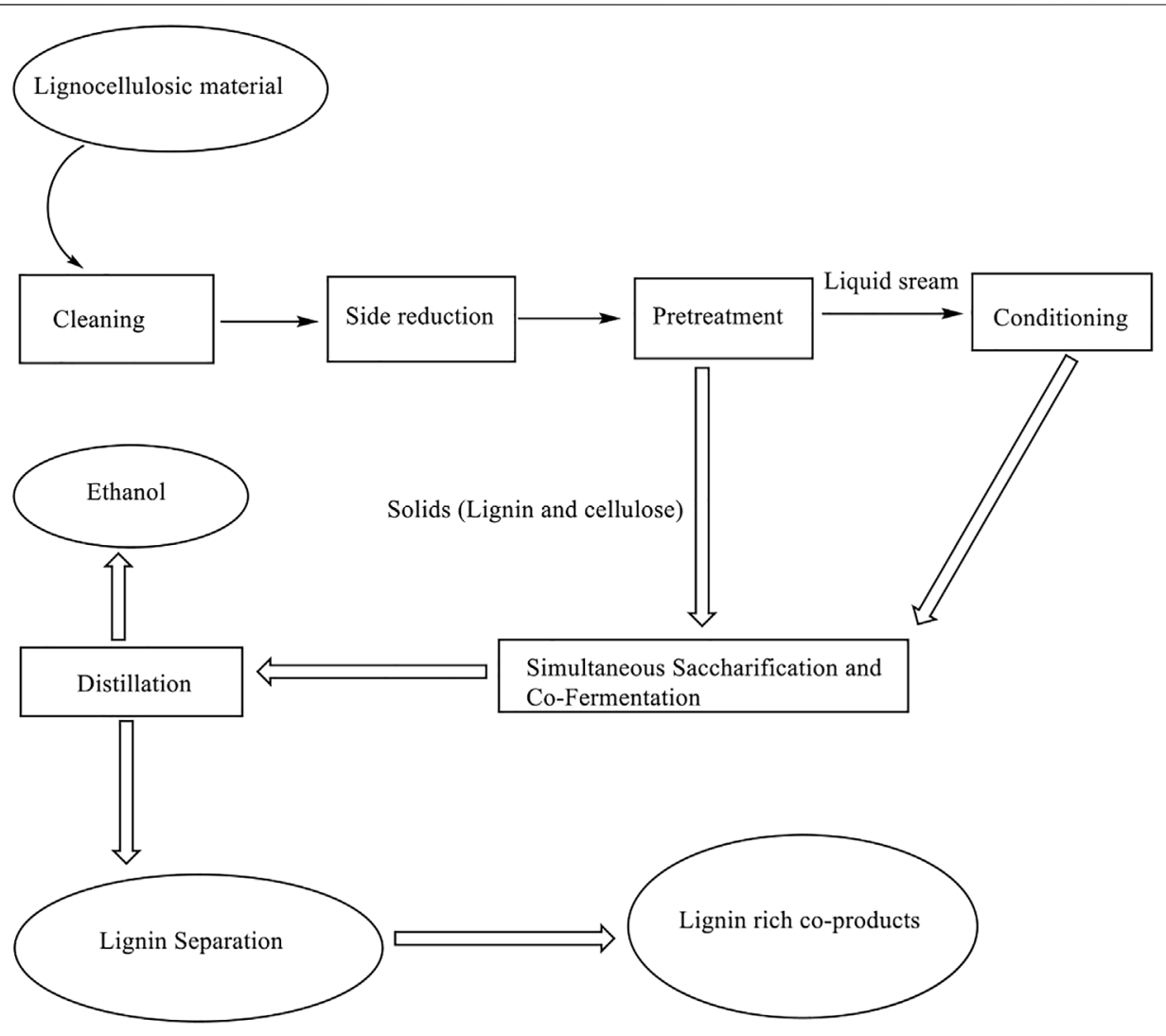

FIGURE 2 | Illustration of common ethanol production unit.

lignin (Saha, 2005; Taherzadeh and Karimi, 2008); the essence of this is to make the conversion process as simple as possible; however, despite the success attained with the reported methods, the methods still suffer from certain limitations such as long residence time, generation of toxic residues, and high power consumption.

\section{Physical Pretreatment}

This may also be referred to as mechanical treatment. It involves size reduction treatments that do not change the lignocellulosic waste composition but change size, shape, and bulk density. Methods employed include cutting, milling, grinding, extrusion and irradiation. In most cases, physical treatment is applied first in preparation for other treatment processes. The treatment helps increase the available surface area of lignocellulose for interaction. When the milling method is used in size reduction, the relationship between the final size obtained and milling energy is not linear; moreover, the type of lignocellulosic material, initial material size, and moisture content influence the milling energy required (Liu et al., 2020). The energy eventually relies on the final particle size and the magnitude of crystallinity reduction. Although the treatment enhances reactivity, the physical structure is altered, which is the case for cellulose where crystallinity is reduced, making it susceptible to chemical attack; when this happens, the cellulose becomes more amorphous, favouring hydrolysis at low temperature (Zhao et al., 2006; Yu and Wu, 2010). Reduction in crystallinity and particle size is determined by the type of lignocellulosic material, milling method and process time (Kumar et al., 2017). A study on the pyrolysis of wheat straw using hammer-milling and rod-milling as pretreatment steps showed a significant reduction in particle size and crystallinity of the biomass, which led to high surface area and pore volume of the wheat straw (Bai et al., 2018). Recently, a combination of physical treatment and catalysis known as mechanocatalysis has gained wide attention. A good example of this is the milling of lignocellulose followed by the use of a catalyst to enhance conversion rate. A study on the effect of planetary ball milling on wood fibre gave rise to high xylose and glucose via enzymatic hydrolysis (Gu et al., 2018). Previous authors have shown that the inclusion of mineral acid to cellulose agitation in a mill aids hydrolysis to glucose (Hick et al., 2010; Meine et al., 2012; Shrotri et al., 2013) which can be fermented for biofuel production. However, this is not a direct route process; in most cases, mechanocatalysis leads to the production of a composite of depolymerized materials (Carrasquillo-Flores et al., 2013), which may promote the removal of hemicellulose and lignin.

\section{Steam Explosion}

The lignocellulosic material is treated with high-pressure saturated steam to disrupt bonding between polymeric components in order to break the lignocellulose structure, as 


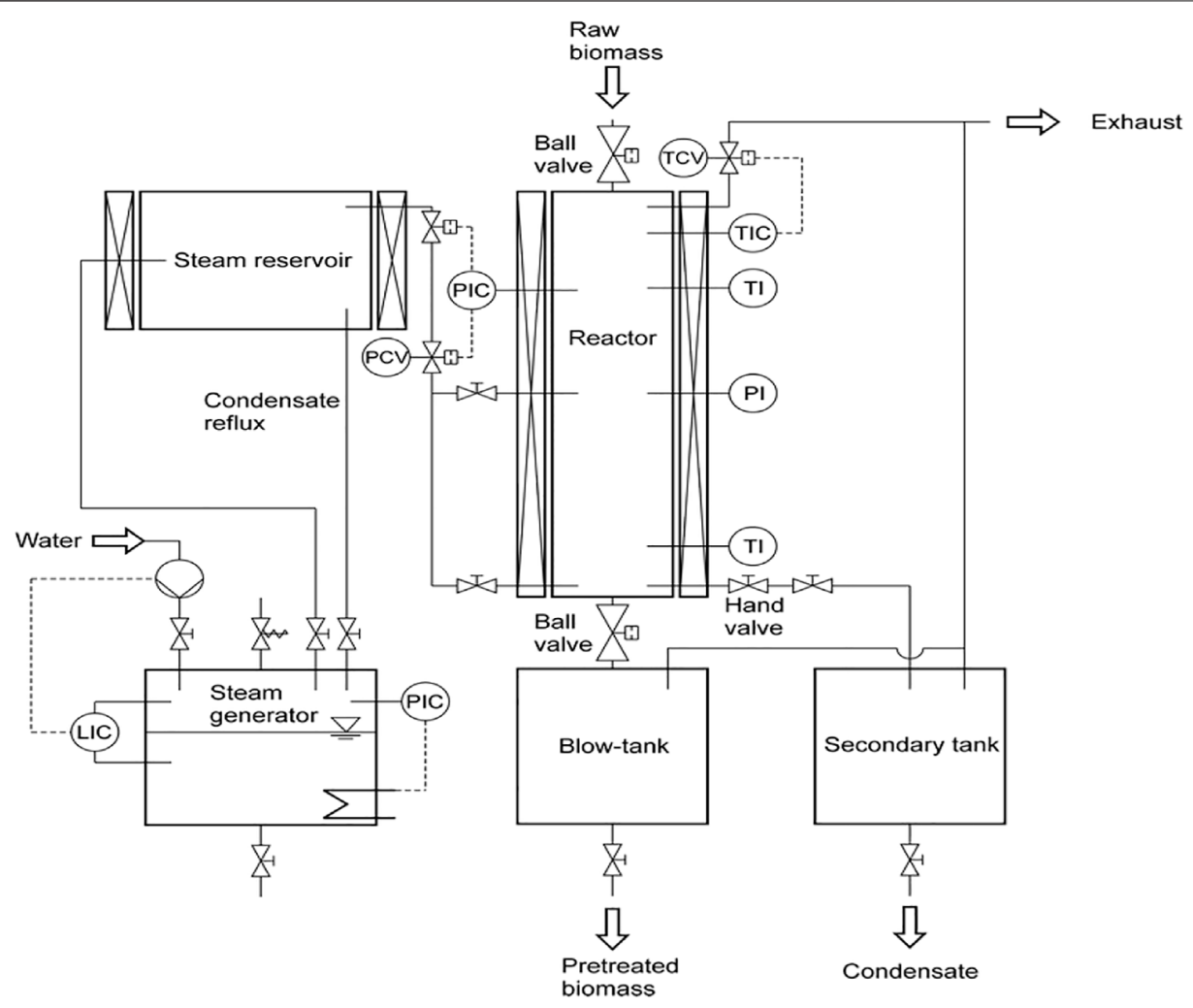

FIGURE 3 | Description of steam explosion pretreatment system (Pielhop et al., 2016).

shown in Figure 3. It is a physicochemical process that is initiated at a temperature of about $433-533 \mathrm{~K}$ and pressure of $0.69-4.83 \mathrm{MPa}$; the process is brought to an end by an explosive decomposition of the material. The observed 'explosion' is due to the depressurization and cooling of the biomass, which causes the water in the biomass to explode. The process enhances cellulose hydrolysis by degrading hemicellulose and lignin (Varga et al., 2003; Ruiz et al., 2006). The process is catalyzed by hot water or organic acids released via hemicellulose degradation; in some cases, an acid catalyst such as sulphuric acid may be added to boost the hydrolysis and help reduce sugar degradation (Weil et al., 1997; Stenberg et al., 1998). The inclusion of acid, referred to as acid-catalyzed steam explosion, improves enzymatic hydrolysis of cellulose to promote the removal of hemicellulose. The process is relatively green as it avoids the use of organic solvent and corrosive chemicals, making it of industrial value. Although the method is effective, it cannot wholly fractionate lignocellulose as lignin particles can backagglomerate; some of the possible fractions of chemicals that may arise from lignin as a result of the treatment are presented in Figure 4. Furthermore, sugar obtained can also degrade during the process (Donaldson et al., 1988), leading to the formation of inhibitory by-products that may retard the process. When compared with a mechanical or physical process, steam explosion requires less energy for actualization, and it is most effective for agro-lignocellulosic materials. A study (Li et al., 2011) has shown that pit membrane and the parenchyma of wood is damaged by steam explosion improving permeability. A study on Abies lasiocarpa showed that five kinds of changes could take place in the aspirated pit; these changes may include distortion and depression of the pit membrane, cracking of pit border and cell wall, and breaking of pit torus. A report on the steam explosion treatment of softwood showed that the process could enhance the enzymatic digestibility of lignocellulosic materials (Pielhop et al., 2016).

\section{Ammonia Recycle Percolation}

Ammonia fiber treatment is a physicochemical process that is similar to steam explosion treatment. It uses ammonia at high pressure (2-3 MPa) and moderate temperature (333-373 K). The ammonia treatment is AFEX and ammonia recycle percolation (ARP). During the process, lignocellulose is exposed to ammonia over a period of time. The dosage is about $1-2 \mathrm{~kg}$ of liquid ammonia per $\mathrm{kg}$ of lignocellulosic material; AFEX significantly improves fermentation rate (Zheng et al., 2009) but with low solubility of hemicellulose. However, improved hydrolysis of hemicellulose and cellulose is possible. Care must be taken to recover ammonia vapour from the environment (Sun and Cheng, 2002). The approach is green and improves the surface area, digestibility and enzyme accessibility (Kamiya et al., 2008). The ammonia can be recovered and reused. Unfortunately, the process does not remove hemicellulose significantly and may reduce final sugar yield. The process is not efficient for lignocellulosic material 


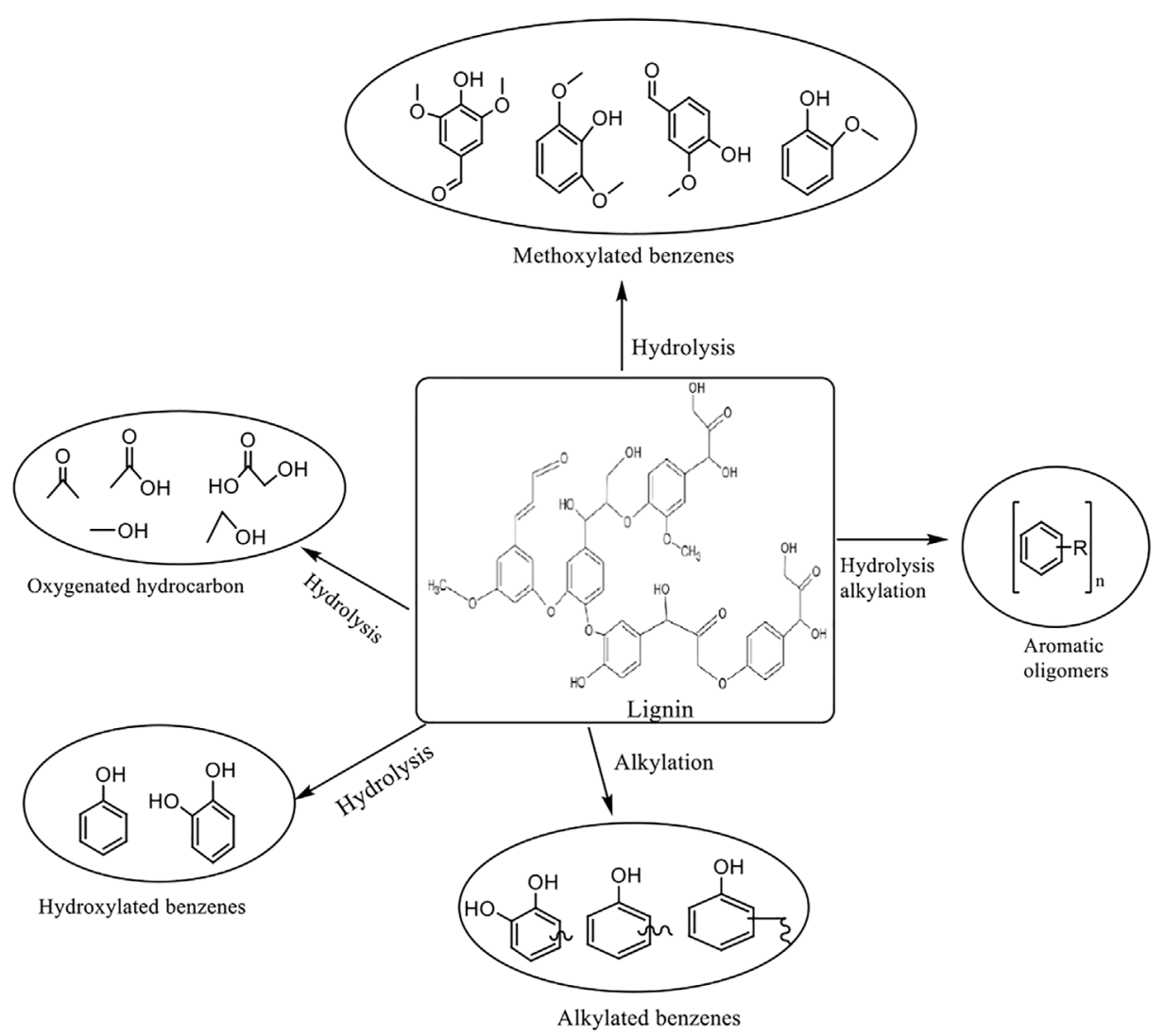

FIGURE 4 | Proposed subunits of lignin through a steam explosion process.

with high lignin content (Taherzadeh and Karimi, 2008). During the ARP process, aqueous ammonia is passed through the lignocellulosic material at a high temperature of about 423-443 K (Galbe and Zacchi, 2007). The ammonia reacts with lignin causing depolymerization and cleavage of lignin-carbohydrate linkages. A study on silver grass revealed that moisture content of lignocellulosic material plays an essential role in AFEX (Lee and Kuan, 2015). Mainly ARP makes use of aqueous ammonia solution while AFEX relies on liquid ammonia. Both processes do not produce process inhibitors and reduce lignin and hemicellulose with improved cellulose hydrolysis (Sun and Cheng, 2002). The energy required for ARP is higher than that of AFEX due to the high temperature and longer contact time of the process.

\section{Chemical Pretreatments}

Chemical pretreatment aims at removing hemicellulose and lignin in order to improve the biodegradability of cellulose. Presently, supercritical $\mathrm{CO}_{2}$ fluid is commonly used in the treatment of wood.

\section{Acid Pretreatment}

During acid pretreatment, the rigid structure of lignocellulosic materials is broken into simple sugar, which can be fermented into biofuel. The process leads to the disruption of intra and intermolecular forces holding the components of the lignocellulosic materials together, which results in the reduction of cellulose and solubilization of hemicellulose ( $\mathrm{Li}$ et al., 2010). Acid pretreatment can be achieved using either concentrated acids at low temperatures or dilute acids at high temperatures. Using concentrated acids at low temperatures increases the sugar conversion rate; however, the concentrated acids come with disadvantages of being corrosive, toxic and increase process cost due to additional maintenance cost; apart from this, it might lead to undesired products from cellulose degradation. Dilute acid is sometimes used because it permits high reaction rates with improved cellulose hydrolysis; however, lignin hardly solubilizes in either dilute or strong acid concentration, but it gets disrupted to a great extent to allow for easy access to cellulose hydrolysis. Therefore, many industrial processes would prefer the use of dilute acids. Several methods have been developed using inorganic and organic acids. Authors have reported the use of phosphoric acid on wheat bran in preparation for enzymatic hydrolysis and, subsequently ethanol production (Nair et al., 2015). Corn stover has been pretreated with nitric acid for the production of bioethanol (Kim et al., 2015). Formic acid has also been reportedly used in the hydrolysis pretreatment of functional cellulose nanofibrils (Du et al., 2016); oxalic acid (Jeong and Lee, 2016) and maleic acid (Jung et al., 2015) have also been reported as chemical 
pretreatment agents for lignocellulosic materials in biofuel production. It is very important to understand reaction kinetics and the nature of the lignocellulosic material in order to design, configure, and operate a suitable reactor for acid pretreatment. Previous studies showed that hemicellulose is converted to xylose by a first-order reaction; complete conversion of lignocellulose materials with low and high furfural is a two-stage process. The first stage involves slow hydrolysis of hemicellulose with concentrated acid producing hemicellulosic sugars while the second stage is the fast hydrolysis of hemicellulose and hydrolysis of cellulose to glucose (Amin et al., 2017). A study on wild rice grass compared the use of dilute acid $\left(\mathrm{H}_{2} \mathrm{SO}_{4}\right)$ and alkali $(\mathrm{NaOH})$ pretreatment on enzymatic hydrolysis of biomass (Sahoo et al., 2018). The results revealed and supported the feasibility of dilute acid treatment over alkali treatment. Several other studies have also supported the use of $\mathrm{H}_{2} \mathrm{SO}_{4}$ as a suitable treatment agent in acid pretreatment (Sindhu et al., 2014; Kärcher et al., 2015).

\section{Alkali Treatment}

This treatment is commonly used in the solubilization of lignin. It causes the breakdown of ester and glycosidic side chains in the structure of lignin; the cellulose becomes swollen with a reduction in the degree of crystallinity while hemicellulose is solubilized (Sills and Gossett, 2011; Badiei et al., 2014; Behera et al., 2014; Maurya et al., 2015). Alkaline solutions used include calcium, ammonium, sodium and potassium hydroxide. However, sodium hydroxide is commonly used, and it is the most frequently reported and the most effective (Zhu et al., 2010; Kim et al., 2016); however, its usage leads to the production of methane gas which is unwanted and, as a result limiting the use of sodium hydroxide on an industrial scale (Zheng et al., 2009). This concern has shifted attention towards the use of potassium hydroxide (Jaffar et al., 2016) as well as calcium hydroxide (Singh et al., 2015). Studies on corn, switchgrass, bagasse, wheat, and rice straw have been documented (Zhu et al., 2010; Satlewal et al., 2018; Zheng et al., 2018; Tan et al., 2021). The use of alkaline leads to saponification reaction, which helps promotes the accessibility of enzymatic interaction (Sun et al., 2016). The process is very effective when the lignocellulosic material contains a low amount of lignin. An author (Kim, 2018) revealed the use of empty palm fruit bunch fibre using alkali pretreatment $(\mathrm{NaOH}$, $0.5-2.0 \mathrm{M})$ at $121^{\circ} \mathrm{C}$ and $60 \mathrm{~min}$ for bioethanol production. The result revealed a delignification yield in the range of 55.4-56.9\%; the fermentation process yielded $21 \mathrm{~g} \mathrm{~L}^{-1}$ ethanol within $28 \mathrm{~h}$; the overall scheme for the reported process is as shown in Figure 5. Similarly, the effect of alkaline pretreatment has been reported on a cotton stalk (Dimos et al., 2019). Other authors have reported a combined process where alkaline pretreatment and other pretreatment steps are combined for effective and efficient treatment. An example of this is a two-step process based on alkaline and hydrothermal treatment of wheat straw for improved enzymatic saccharification (Sun et al., 2018). The treatment helped improve the production of bioethanol; a schematic illustration of the process is shown in Figure 6. A few studies, like the alkaline pretreatment of rice straw using $1 \% \mathrm{NaOH}$ (Shetty et al., 2017), have revealed the advantages of the alkali

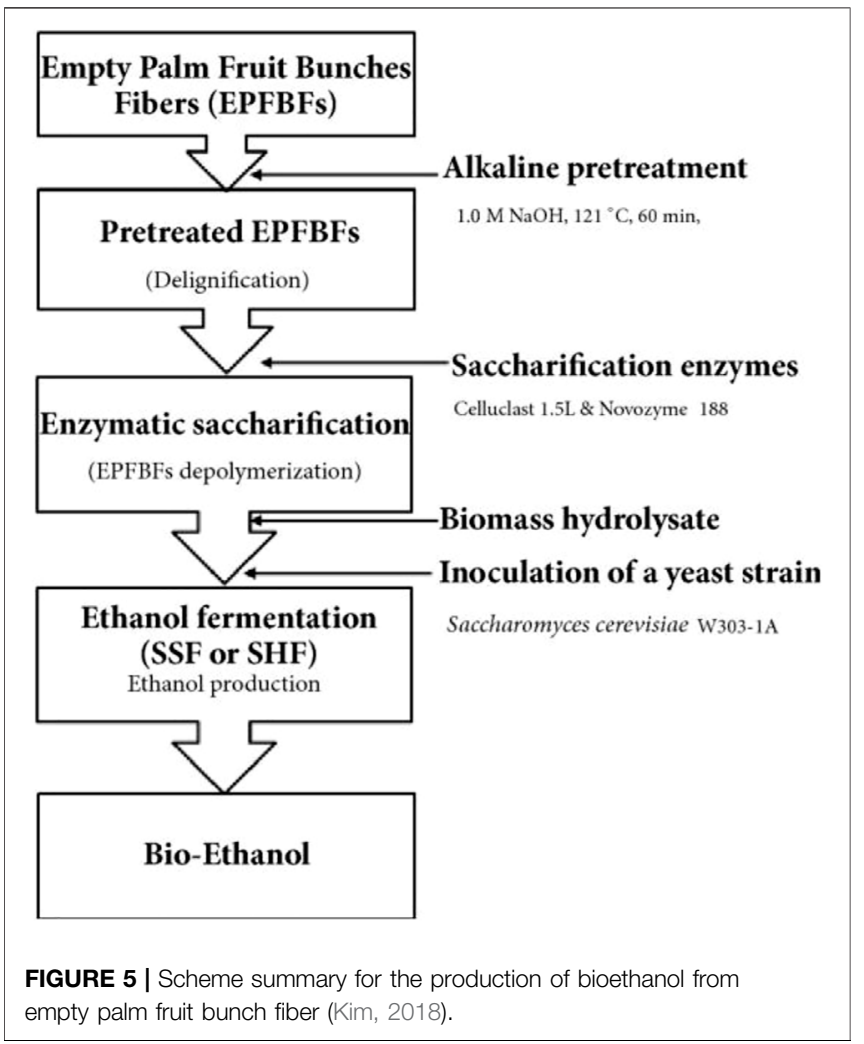

treatment step by reducing lignin and hemicellulose content. Another study (Shen et al., 2017) optimized the conditions applied for the pretreatment step in converting vinegar residue to biofuel.

\section{Biological Treatment}

Biological treatment of lignocellulosic materials is conducted to degrade the materials; the process may involve fungal pretreatment, enzymatic hydrolysis and aeration (Rafieenia et al., 2018). The fungi secrete the enzymes which are involved in the hydrolysis of cellulosic compounds to simple fermentable sugars. A few enzymes such as xylanase, hemicellulase, $\alpha$-amylase, and arabinose have been identified that can be used directly to achieve hydrolysis (Cui et al., 2010; Zhao et al., 2012). The bioprocess is safe and environmentally friendly (Okano et al., 2005; Pan et al., 2006). The enzymes required for the hydrolysis are mostly fungi produced; they may be classed as soft, brown and white-rot fungi. However, the most studies and promising among the white fungi class is the Basidiomycetes. It has been shown that few of the white-rot fungi can degrade polysaccharides and lignin while others will selectively degrade lignin; in whichever process that a particular white-rot fungi displays, two extracellular enzymatic systems may be involved, which are hydrolytic and ligninolytic systems. The hydrolytic system describes the degradation of cellulose and hemicellulose, while the ligninolytic system describes the depolymerization of lignin (Vats et al., 2013; Wagner et al., 2018). During pretreatment, the white-rot is used as a whole-cell organism. Common whiterot fungi reported for the ligninolytic pretreatment are Pleurotus 


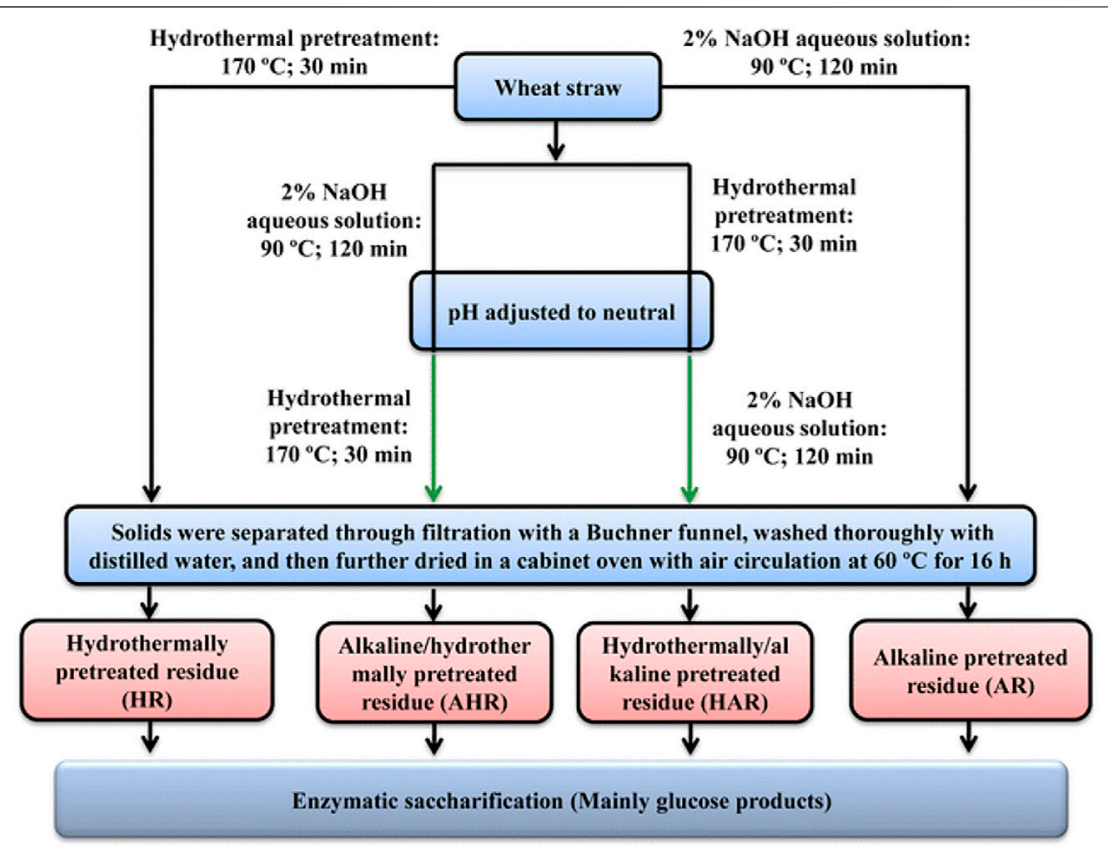

FIGURE 6 | Schematic illustration of one-step process based on hydrothermal and alkaline treatment (Sun et al., 2018).

streatus, Ceriporia lacerate, Ceriporiopsis subvermispora, Pleurotus ostreaus, Gloeophyllum trabeum, Cyathus stercolerus, Postia placenta, Pycnoporus cinnarbarinus, Phanerochaete chrysosporium, and Phlebia subserialis (Kumar et al., 2017; Baruah et al., 2018). Despite the performance reported for white-rot fungi, it still faces the challenge of not being able to adequately degrade lignin because of the carbon-carbon bonds in the lignin polymeric structure (Martinez et al., 2004). One disadvantage of the biological process is the slow rate of the process; apart from this, the microorganisms also consume carbohydrates for metabolic activity. However, most times, the enzymatic biological treatment is carried out in combination with other pretreatment methods in order to achieve high efficiency (Zhao et al., 2012). Other processes have made use of accessory enzymes laccase and xylanases in order to control the amount of enzyme needed to complete the conversion as well as to achieve cost-effectiveness. In fact, a previous study has revealed that the degradability of lignocellulosic material by enzymes depend on the degree of lignification, crystallization, and acetylation of the material (Chang and Holtzapple, 2000). The strength and extent of bonding among lignin, cellulose, and hemicellulose content further affect the hydrolysis conversion process (Tarasov et al., 2018). Deacetylation and delignification are two important processes that require attention in order to achieve complete conversion as these processes may produce substances that may inhibit the conversion process of lignocellulosic material if care is not taken (Chang and Holtzapple, 2000). Therefore, the processes must be monitored for the removal of chemical inhibitors of hydrolysis. In a previous study, the use of Saccharomyces cerevisiae resulted in an alcohol yield of $90 \%$, but it is unable to ferment xylose and arabinose sugars and limited in the operational temperature range (McMillan, 1994; Jørgensen,
2009). Although the study on Zymomonas mobilis (bacteria) gave a high yield of alcohol, it has a low tolerance to chemical inhibitors with a neutral $\mathrm{pH}$ range (McMillan, 1994). Several authors have reported the use of some microorganisms for biological pretreatment at specified conditions, as shown in Table 3. When an adequate pretreatment is given to a lignocellulosic material, the amount of fermentable sugar after saccharification increases, increasing the total process efficiency.

The hydrolysis by enzymatic activity is affected by the level of accessibility of cellulose by cellulase. There is a relationship between enzyme accessed site and rate of hydrolysis. The performance of cellulase is not only affected by lignin but by xylan as well. Despite the fact that the presence of lignin and xylan affects the performance of cellulase, the influence of xylan on the accessibility of cellulase is more than that of lignin (Sindhu et al., 2016). This has indicated the need for the supplementation of accessory enzymes in order to improve efficiency. There has been a study on the isolation and purification of accessory enzymes in order to develop an eco-viable process for efficient hydrolysis to bioethanol. The accessory enzymes act on linkages in plant cell walls; they include galactanase, arabinases, pectinases, and lyases.

Certain factors are known to affect the biological pretreatment process. The nature and type of lignocellulosic waste used plays an important role; this includes the distribution of cellulose, hemicellulose, lignin and other components in the lignocellulosic waste. Constituents like lipid, protein, and salts affect the treatment process. Since the lignocellulosics are biological and mostly plant-sourced, the growth condition and maturation before harvest goes a long way in determining the constituents and distribution of the compositions. The incubation time needed for the treatment is a factor to be considered. Suppose the incubation time is too long, the process cost 
TABLE 3 | Different microorganisms reported for biological treatment of lignocellulosic wastes.

\begin{tabular}{|c|c|c|c|}
\hline Lignocellulosic material & Microorganism & Process effect & References \\
\hline Wheat straw & Ceriporiopsis subvermispora & Minimal cellulose loss & Cianchetta et al. (2014) \\
\hline Eucalyptus grandis saw dust & P. ostreatus/P. pulmonarius & Twenty fold increase in hydrolysis & Castoldi et al. (2014) \\
\hline Straw & Fungal consortium & Seven fold increase in hydrolysis & Taha et al. (2015) \\
\hline Sorghum husk & Phanerochaete chrysosporium & Increase in reducing sugar production & Waghmare et al. (2018) \\
\hline Japanese cedar wood & Ceriporiopsis subvermispora & $28 \%$ lignin removal in initial substrate & Amirta et al. (2006) \\
\hline Corn stover silage & Phanerochaete chrysosporium & $\begin{array}{l}39 \% \text { lignin removal of initial substrate, improved degradationof } \\
\text { substrate cell wall components }\end{array}$ & Liu et al. (2014) \\
\hline Yard trimmings & Ceriporiopsis subvermispora & $20.9 \%$ degradation of initial lignin content & Zhao et al. (2014) \\
\hline Rice straw & Pleurotus ostreatus and Trichoderma reesei & $\begin{array}{l}33 \% \text { lignin removal of initial substrate with wrf and } 23.6 \% \text { with } \\
\text { brf lignin-to-cellulose ratio after treatment: wrf } 4.2 \text {, brf } 2.88\end{array}$ & Mustafa et al. (2016) \\
\hline Rubber wood & Ceriporiopsis subvermispora & Increased fermentation yield & Forough et al. (2013) \\
\hline Agropyron elongatum & Flammulina velutipes & Improve biodegradation & Lalak et al. (2016) \\
\hline
\end{tabular}

increases which, in the long run, discourages the use of biological pretreatment. The incubation time must be short. The optimum process temperature is also a key factor that determines the success of biological pretreatment. The temperature depends on the type of microorganism and lignocellulosic waste used. The higher the temperature, the higher the energy consumption and the overall cost go up. If heat is unnecessarily accumulated, it can have a negative impact on the success of the process. The type of microorganism used affects the process. Several microorganisms have been identified over time. Fungi and bacteria have been used. Many studies have revealed that the use of a combination of fungi can help give an effective result. The particle size of the lignocellulosic material and process $\mathrm{pH}$ are essential. The smaller the particle size, the larger the available surface for interaction for the pretreatment. The penetration of the fungi is limited when the particle size is large, which further prevents air and water diffusion as well as other metabolite products into the lignocellulosic particles. The $\mathrm{pH}$ is an important factor in cultivating the fungi; report has shown that white-rot performs well in $\mathrm{pH}$ range of 4-5 (Sindhu et al., 2016).

\section{Saccharification System for Converting Cellulose and Hemicellulose to Bioethanol}

Before the conversion of cellulose and hemicellulose to bioethanol, pretreatment of lignocellulosic waste is an essential step in the production of bioethanol from lignocellulosic waste to improve the accessibility of degrading enzymes to cellulose and hemicellulose. The effect is to improve the yield from saccharification. The pretreatment step also further helped reduce the cost of production, although a few authors reported the pretreatment step to be one of the most expensive steps in converting cellulose to bioethanol (Alvira et al., 2010; Kim et al., 2011). Some of these pretreatment steps have been mentioned above, however, more sophisticated and advance processes might involve using an advanced fractionation method to obtain a highly purified bioethanol as a high-grade biofuel. The use of acidified zinc chloride in effective fractionation has been reported (Yoo et al., 2012; Kim et al., 2013), which is effectively designed to separate hemicellulose units containing xylan. The use of zinc chloride showed many advantages, such as being very effective in enhancing enzymatic digestion of cellulosic waste, which promotes the ease of fermenting the wastes to ethanol (Yoo et al., 2012). A study (Kim et al., 2014) reported hemicellulose hydrolysis from barley straw and enzymatic saccharification. The study evaluated the effect of process parameters such as the effect of reaction time, temperature and concentration of zinc chloride on the conversion process. The study further revealed that the use of zinc chloride improves the solubility of hemicellulose and enhances the enzymatic digestion of treated cellulose.

The saccharification involves the use of cellulases (for cellulose) and hemicellulases (for hemicellulose) in enzymatic hydrolysis to degrade polysaccharides (hemicellulose and cellulose) to fermentable sugars. It is obvious that cellulase plays an essential role in catalyzing the process. The catalase may be sourced from plants, fungi, and bacteria; based on structural properties, three key types of cellulase activities are involved in the hydrolysis of cellulose, including endoglucanases and exoglucanases and $\beta$-glucosidases (Menon and Rao, 2012). Cellulose hydrolysis may involve individual enzymes or a multi enzymatic process with modular structure in both cases. The enzymes have a catalytic site where the hydrolytic reaction occurs and a domain where it binds to the cellulose; both the hydrolytic site and the cellulose-binding domain of the enzyme are linked by a peptide (Carrard et al., 2000). The best operating condition reported for most cellulase is $\mathrm{pH}$ value within the range 4.0-5.0 and temperature of $50^{\circ} \mathrm{C}$ (Kristensen, 2008; Świątek et al., 2014; Walker et al., 2018). Depending on the residue sugar, hemicellulose can be classified into two groups, with the common groups being xylan and mannan. Since the presence of hemicellulose shields access to cellulose, its removal reduced the amount of cellulase required for the hydrolysis of cellulose. Xylan's main polysaccharide chain is degraded by endoxylanases into monomers, including smaller $\beta$-xylosidase and oligosaccharides that finally separates into xylose. Furthermore, mannan can be degraded by $\beta$-mannosidase and endomannanase. Understanding the structural mode by which the enzyme binds to the polysaccharides can really help in having insight into the mechanism of saccharification. Knowledge of the mechanism guides in designing the most appropriate approach or condition for the process. Although it is not as simple as it may 
seem due to the inherent homogeneity and complexity of cellulose; however, understanding the molecular mechanism behind cellulose and hemicellulose degradation is an important factors in designing the most appropriate approach for saccharification process (Louime et al., 2011).

Trichoderma reesei is the most common source of cellulases; however, enzymes from Trichoderma reesei has been reported to exhibit low-glucosidase activity leading to incomplete hydrolysis of cellobiose (Holtzapple et al., 1992). It is important that the required cellulase should be highly active on the lignocellulosic waste for hydrolysis (Knauf and Moniruzzaman, 2004). Other studies have also been reported that involved the use of acid (Hamelinck et al., 2005); a major disadvantage of this is the fact that the process requires a high amount of acid, which makes it less attractive. It mostly leads to chemical dehydration of monosaccharides, causing the formation of other undesired products in biofuel produced. Hemicellulases contain catalytic and non-catalytic modules. The catalytic modules are either carbohydrate esterases or glycoside hydrolases. The noncatalytic modules contain the carbohydrate-binding domains, which promotes the binding of the catalytic domain to either the enzymatic complexes or microbial cell surface (Shallom and Shoham, 2003; Menon and Rao, 2012). Several microorganisms have been studied as alternative sources of cellulase for hydrolysis of cellulose; some of the reported organisms for this purpose include Candida tropicalis, Trichoderma harzianum, Aspergillus niger, Fusarium oxysporum, and Trichoderma sp. (Mattam et al., 2016; Mezule et al., 2016; Mkhize et al., 2016; Mishra and Jana, 2017). Recently, some authors (Hwangbo et al., 2019) reported a one-step saccharification of pretreated lignocellulosic biomass using immobilized magnetite biocatalyst system. The authors reported five saccharifying enzymes namely endo-1,4- $\beta$ xylanase (an endoxylanase, xynC), endo-1,4- $\beta$-D-glucanase (an endoglucanase, eglS), $\beta$-xylosidase (bxlB) and cellobiohydrolase (an exoglucanase, cbhA), and $\beta$-glucosidase $(\mathrm{bglH})$. These enzymes performed better than commonly used enzymes with better reusability. It has also become important to optimize saccharification conditions of lignocellulosic biomass for biofuel production. A recent study (Kucharska et al., 2020) revealed the use of Box-Behnken design as a promising approach for achieving this. Furthermore, other authors (Navarro et al., 2018) applied simultaneous enzymatic saccharification and comminution on lignocellulosic biomass (Figure 7) as a promising approach towards biofuel conversion, the approach achieved a saccharification efficiency of $80 \%$ at $\mathrm{pH}$ six using an energy consumption of 50 M.J. $\mathrm{kg}^{-1}$ biomass.

\section{Fermentation Strategies}

Saccharification is followed by fermentation which involves degrading the sugars in the presence of microorganisms into alcohols and other end products. Saccharomyces cerevisiae is the commonly used yeast that secrets enzyme that converts the sugars to ethanol at a temperature of about $30^{\circ} \mathrm{C}$ under anaerobic conditions with the generation of $\mathrm{CO}_{2}$ and $\mathrm{N}$-based compounds as by-products. Despite the achievement with the use of Saccharomyces cerevisiae, it is unable to ferment pentose sugar. Presently, research is focused on developing a microorganism system that ferments pentose and hexose sugars. Over time, two major approaches are known for the conversion of sugar to ethanol, namely, simultaneous saccharification and fermentation (SSF) and separate hydrolysis and fermentation (SHF). During SHF, the microorganism is added at the end of the hydrolysis in separate units. The process has shown some inherent limitations over time, including the formation of process inhibitors, contamination, need for co-equipment, and time consumption. In SSF, the hydrolysis and the enzymatic fermentation takes place in the same unit and simultaneously, which is more effective than SHF. However, in SHF, the inhibitory effect is neutralized; enzymes such as Kluveryomyces, Saccharomyces, Zymomanas, Pichia and Debaryomyces as well as their recombinants, have been reported (Philippidis, 2018). SSF has proved to be a better approach for lignocellulosic biomass (Kim and Holtzapple, 2006). The success of SSF depends on compatibility with process parameters such as temperature, $\mathrm{pH}$, substrate concentration, kinetic, etc. (Doran-Peterson et al., 2010). One major advantage with the use of SHF is that each step involved in the process can be achieved at its optimal conditions to attain high product recovery (Dey et al., 2020). The process may require dilute media, which makes the product to be of low concentration and may require high enzyme dosage as well. Some level of freedom exists in SHF because the processes are carried out in separate vessels; however, this incurs additional production cost, which is not the case in SSF; although this additional production cost may be substantiated. Due to the level of purity that may be attained in SHF as a result of the removal of solid fractions after the enzymatic hydrolysis, the yeast may be recycled and reused, which is not possible in SSF. Therefore, in SSF, the yeast has to be prepared for each batch process, which suggests that sufficient Saccharomyces cerevisiae will have to be cultivated for the fedbatch mode to prevent low yield due to glucose repression; apart from this, care must be taken to avoid inhibition by the medium. Conclusively, the choice between SSF and SHF will depend on factors like product size, desired product spectrum in the biorefinery, and feedstock quality.

Apart from SHF and SSF, the use of simultaneous saccharification and co-fermentation (SSCF) and consolidated biomass processing (CBP) have been developed. There has been tremedous progress in the use of SSCF by developing an appropriate microorganism system for xylose fermentation. Genetically modified microorganisms with different approaches have been developed (Manzanares, 2010). SSCF is recognized as a possible means for ethanol production from xylose-rich lignocellulosic wastes with a genetically engineered strain of Saccharomyces cerevisiae (Olofsson et al., 2008; Bertilsson et al., 2009). A study (Olofsson et al., 2010) using SSCF increased ethanol yield from 40 to $50 \%$. SSCF of steamexploded corn stover has been compared with other conversion processes (Liu and Chen, 2016). The study revealed the yield, concentration, and productivity of ethanol to be $90.0 \%, 34.3 \mathrm{~g}$ $\mathrm{L}^{-1}$, and $2.61 \mathrm{~g} \mathrm{~L}^{-1} \mathrm{~h}^{-1}$, respectively, for the co-fermentation of $60 \mathrm{~g} \mathrm{~L}^{-1}$ glucose and $10 \mathrm{~g} \mathrm{~L}^{-1}$ xylose by Saccharomyces cerevisiae 


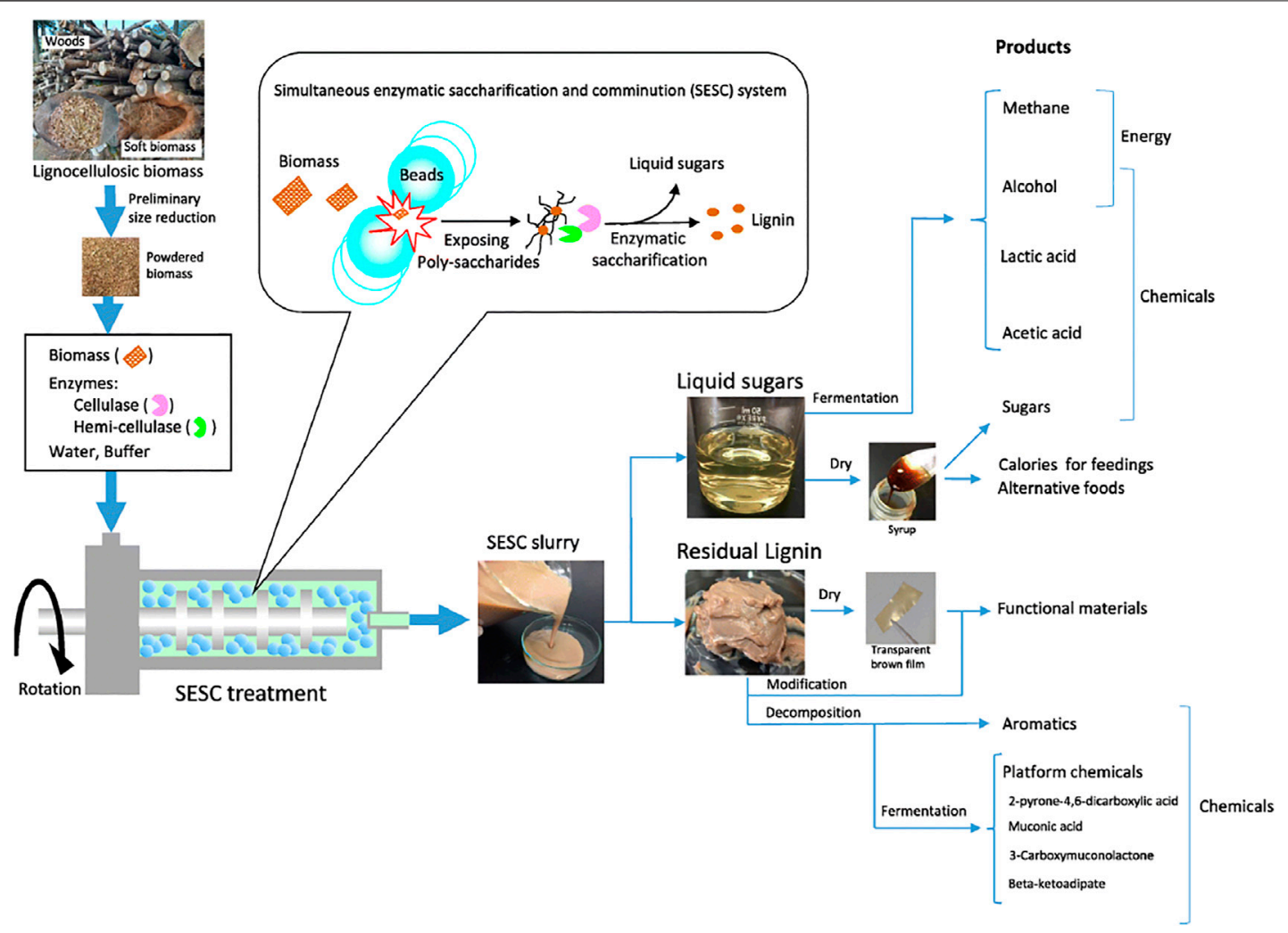

FIGURE 7 | Valorization of lignocellulosic biomass by the SESC process (Navarro et al., 2018).

IPE003. It was concluded that SSCF increased ethanol production and can serve as an efficient lignocellulosic waste conversion process to ethanol. Another report (Sekhon et al., 2018) further revealed that the production of ethanol from insoluble fiber doubled when SSCF with S. cerevisiae and E. coli KO11 was used as a conversion process. The three major steps involved in the lignocellulosic biomass conversion (enzymes production, biological hydrolysis of biomass to sugars and oligomers, and fermentative metabolites production) can be combined into a single process known as CBP. The process makes use of a single type of microorganism in a single reactor via a biomass-tobioethanol conversion technology. The focus of CBP research has been on developing a more efficient microorganism for a well-designed process condition; this has led to the development of several mesophilic/thermophilic and cellulolytic/noncellulolytic microorganisms. These microorganisms include the use of Thermoanaerobacterium saccharolyticum, Clostridium thermocellum, Caldicellulosiruptor bescii, Clostridium phytofermentans, S. cerevisiae, K. marxianus, etc. (Shaw et al., 2008; Shao et al., 2011; Jin et al., 2012; Yamada et al., 2013; Chung et al., 2014). Genetically modified strains of microorganisms have also been developed for this purpose. Thermophilic microorganisms have the advantage of higher hydrolysis rate and less susceptibility to contaminations at high temperatures than the mesophilic group that are limited with high operation temperature (Olson et al., 2012). Recently, a study (Cunha et al., 2020) reported the use of engineered industrial Saccharomyces cerevisiae strains (whole-cell biocatalysts) as a promising commercial enzymatic cocktail for the production of ethanol from corn cob biomass. Other authors have also documented a one-pot CBP as a potential means for techno-economic feasibility of lignocellulosic-bioethanol-fuel production (Vaid et al., 2018). The authors optimized bioethanol production from pine needle biomass via single pot in-situ ionic liquid-based pretreatment and enzymatic saccharification. The adopted process produced a maximum ethanol yield of $0.148 \mathrm{~g} \mathrm{~g}^{-1}$ pine needle biomass in $72 \mathrm{~h}$ resulting in an efficiency of $41.39 \%$. Table 4 shows bioethanol yield from some selected lignocellulosic materials. Sugarcane bagasse and switch grass are good sources of bioethanol which should be better made use of. Large amount of these are continuously generated from both local and international industries which can be used as sources of cheap raw materials for bioethanol production.

Optimization of fermentation condition is very crucial in order to obtain the best of yield and product. Obviously, the type of lignocellulose source, fermentation time, yeast amount are key conditions that should not be underplayed. Apart from ensuring an efficient pretreatment step, it is important to also use an efficient recovery process. Most times, there are challenges making use of appropriate recovery process. Recently, there has been attention on bioethanol recovery study in order to improve on the utilization of lignocelluloses. Gas stripping from fermentation broth has been studied to improve production yield. The use of gas 
TABLE 4 | Bioethanol yield from selected underutilized lignocellulose materials.

\begin{tabular}{|c|c|c|}
\hline $\begin{array}{l}\text { Lignocellulose } \\
\text { material }\end{array}$ & $\begin{array}{l}\text { Biethanol } \\
\text { yield }\left(L^{-1} t^{-1}\right)\end{array}$ & References \\
\hline Sugar cane & $70-75$ & Organization, (2008) \\
\hline Cassava & $137-180$ & Organization, (2008) \\
\hline Sugarcane bagasse & $318-500$ & $\begin{array}{l}\text { (Nwakaire et al., 2013; Corbin et al., } \\
\text { 2015) }\end{array}$ \\
\hline Hardwood sawdust & 381 & Corbin et al. (2015) \\
\hline Corn grain & 470 & Corbin et al. (2015) \\
\hline Switch grass & $392-457$ & Corbin et al. (2015) \\
\hline Brassica carinata & 128 & Chin and H'ng, (2013) \\
\hline Wheat straw & 140 & Chin and H'ng, (2013) \\
\hline
\end{tabular}

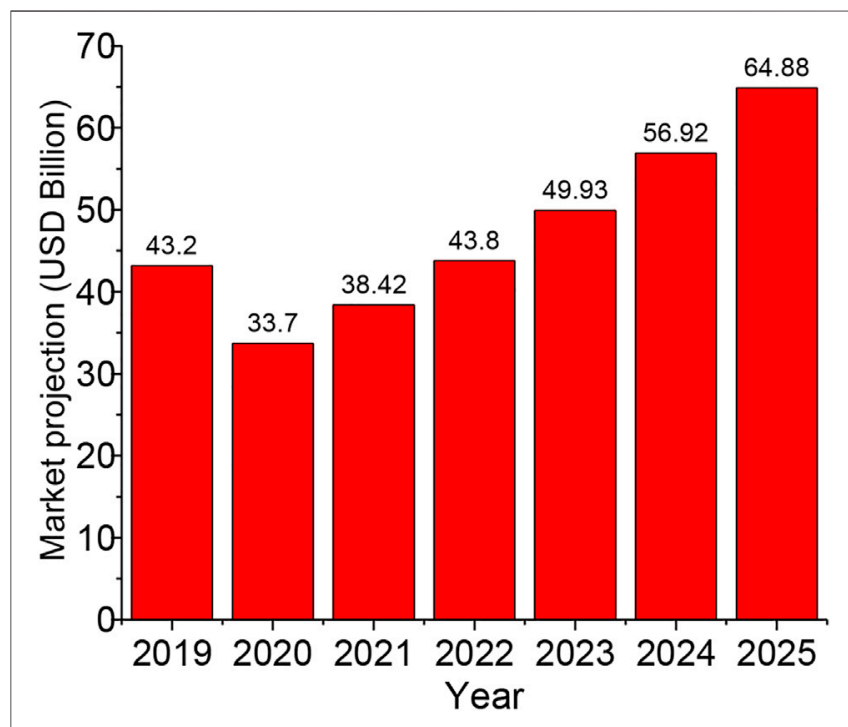

FIGURE 8 | Yearly global size projection of bioethanol market.

stripping has been shown to improve production efficiency (Bušić et al., 2018). Adsorption has also been introduced as a surface phenomenon for effective separation and recovery of ethanol in order to improve yield; which has led to the production of several adsorbents. The process takes place in two stages, the loading stage (adsorption) and the discharge stage (desorption). Application of adsorption as an efficient bioethanol recovery process has focused on the synthesis of cheap and affordable materials as adsorbents with excellent adsorption and desorption capacities. It is important that such adsorbent is easily regenerated for continuous usage. Silicalite-1, activated carbon, zeolite and sepabeads207 have been well used in the recovery of ethanol from broth (Beden et al., 2017; Zentou et al., 2019; Sahlan et al., 2021). Present studies are investigating the use of low-cost biomass adsorbents to achieve this purpose. In fact, other waste generated during the pretreatment and recovery stages can be converted to other chemical products which makes the use of lignocellulose a winwin process.

\section{Challenges, Prospects and Cost Evaluation of Biofuel Production}

The focus of most studies on lignocellulosic waste to bioethanol has been on how to commercialize the product, meaning from cellulose to ethanol technology. As at present, commercialization is still expensive. Most economies in poor developing countries may not be able to sustain the current cost of setting up and running a biofuel plant; however, the governments in some of these countries are trying to help private investors by providing subsidies, tax waivers and agricultural funds to encourage young farmers. The effort is still ongoing to prepare the most efficient and cost-effective technique for biofuel production. The previous global report revealed bioethanol production ( 7.25 billion litres in 2000 to over 46 billion litres in 2007) to be on the increase (Balat, 2007). However, with market size of USD 43.2 billion in 2019 , the global market size projection was estimated at a growth of USD 33.7 billion in 2020 to USD 64.8 billion by 2025 with an expectation of a compound annual growth rate of $14.0 \%$ from 2020 to 2025 (Pattnaik et al., 2021) as shown in Figure 8. The present growth was achieved because of the mandatory usage compelled in many developed countries. On the other hand, the situation is different in many developing countries, most especially those countries in Africa, due to poor policy, lack of support and inconsistent expression of willpower by the government. Although countries like South Africa, Malawi, Zimbabwe, Nigeria, and Kenya have made impacts but the numerous challenges such as land availability, food security, high poverty rate and inadequate government policies still remain major hurdles. China and Brazil are unique exceptions; bioethanol has gained profound usage as blends in the two countries as the government encouraged bioethanol producers with tax reduction and waivers. The feedstock varies in developing countries; despite that, about 25 million hectares of land are available for maize cultivation in Sub-Saharan Africa; the use of its waste in bioethanol production is limited due to poor technology development and low investment. Although the biggest producers of maize and maize waste are South Africa, Nigeria, Tanzania and Kenya, these countries do not have operational maize-fed ethanol plants, and this is the current situation in Sub-Saharan Africa except in South Africa, where this is ongoing. The use of sorghum stalks is increasingly encouraged as a feedstock for bioethanol, most especially in the Philippines, USA, and India but not in Africa, although Africa has large spans of land for sweet sorghum production. Nigeria remains the biggest sorghum producer in Sub-Sahara Africa, estimating for about $39 \%$ of the total production, followed by Sudan, which accounts for about $21 \%$, not excluding Burkina Faso and Ethiopia. Nigeria has considered a large-scale production of sorghum for biofuel production through its Nigerian National Petroleum Corporation with a dedication of about 10,000 ha of land with an estimated production of about 1.5 million litres per day. Although cassava peel is considered for biofuel production, its production rate is low in most developing countries. With the construction of the cassava 
bioethanol plant in Brazil, Nigeria being the largest producer of cassava in Africa, is known for the production of about 50-2000 L of ethanol per day from cassava, although this is in a small processing unit (Ohimain, 2013; Adewuyi, 2020). Despite the expansion expressed in sugarcane in SubSaharan countries, there are challenges with the wetlands, leading to less space for natural habitat, livestock, fisheries and other agricultural practices. This is a pointer for the need for check and balancing. It has become apparent that there could be a decline in water quality due to the water required to grow the crops; this was one of the previous challenges encountered in Brazil by the sugarcane growers. It is expected that irrigation may meet up the shortfall, but with climate change, rainfall is either not sufficient or sufficiently continuous, creating a control challenge in planning and designing efficient irrigation. The decline in water quality may also be in the form of sedimentation and eutrophication, nutrient leaching, and handling of waste generated from ethanol production may also be of concern.

International energy agency has indicated that biofuel can provide $27 \%$ of the total transport fuel by 2050 with the capacity to replace kerosene, jet fuel, and diesel. Due to the high cost of enzymes process conditions, research is focused on developing a cost-effective bio-technique for ethanol production, which is keen on using lignocellulosic material as feedstock. Unfortunately, most reported research works were based on a laboratory scale, indicating the need for large or industrial scale studies to understand better the performance of the newly researched techniques for commercialization. Apart from the benefits that come with the use of biofuel from lignocellulosic materials, studies have highlighted a few negative environmental and socioeconomic challenges that may associate with its use. Some of these may include exacerbation of soil, destabilization of agricultural and forest system, degradation of vegetation and overexploitation of forest (Koh and Ghazoul, 2008; Koul et al., 2011); this has been the case in most developing countries where there are no maintenance and sustenance plans. One major concern is the fear of private investors converting agricultural land meant for food production to biofuel production and may negatively affect the price of food commodities hampering food security (Headey and Fan, 2008). Although the positive aspect of this may include increased soil carbon content, reduced water erosion and wind, and reduced shallow landslides (Börjesson and Berndes, 2006), care still needs to be taken to control biofuel activities. Several other challenges have been identified in developing countries which include poor policy initiatives, market challenges, socioeconomic issues and sustainability. On a global view, developed countries like the United States and European Union have developed advanced techniques for massive food production, which leads to overproduction. Excess of this production is exported to food-importing countries in developing countries at rock bottom prices. Such a move keeps farmers in developing countries out of business as they find it difficult to compete. This negatively impacts agricultural practice, leading to a negative ripple effect on the availability of lignocellulose waste as the farmers quit farming due to the inability to compete in the market. In developing countries with high population and sufficient land for agriculture, the population is a driving force to drive the biofuel market. This is the case in countries like China, Nigeria, India, and South Africa. However, in countries with a small population, like Tanzania, Uzbekistan, and Azerbaijan, a minor investment in land for farming will only be required for biofuel production to meet the national need. Poor infrastructure development is also a challenge; most developing countries have poor road and railway networks, which pose difficulties on logistics and most times contribute to production costs.

Understanding the production cost of biofuel is an integral part of commercialization feasibility. Previous studies have shown that the permissible cost of enzymes may go for about 15-30 cents/gallon of ethanol; however, when lignocellulosic biomass is used as feedstock, the estimated production cost, which includes the pretreatment stage, maybe about 50-80 cents/gallon of ethanol (Chapple et al., 2007). Other authors at the onset of using lignocellulosic materials, preestimated a market cost of about U.S. \$4 per gallon of ethanol (Louime and Uckelmann, 2008). An effort is required to gain a reduction in the estimated cost but the cost of hydrolysis and fermentation is sometimes complicated depending on the source of lignocellulosic feedstock. The cost was previously predicted to be about U.S. $\$ 0.97 \mathrm{~L}^{-1}$ using sugarcane as feedstock (Demirbas, 2010). Economic factors to be considered in biofuel production include the cost of raw materials, transportation, labour, plant capacity, maintenance, process design and capital (Karmakar et al., 2010; Cansino et al., 2013). It has been shown that the cost of raw material covers about $75-80 \%$ of the entire production cost (Bracco, 2015; Gasparatos et al., 2015; Kousoulidou and Lonza, 2016). Authors have shown that the cost of producing bioethanol on a large-scale is about three times higher than that of fossil fuel in developed countries, on the contrary, the cost is lower in developing countries like those in Africa due to readily available agricultural wastes, large span of land for cultivation, and cheap labour (Abila, 2014; Ben-Iwo et al., 2016; Giovannetti and Ticci, 2016). Biofuel production can improve the trade balance of developing countries by substituting imported refined oils with locally made biofuel making such countries depend less on foreign markets to build a more stable macroeconomic business environment. Encouraging the use of lignocellulosic waste creates an avenue for wealth creation from waste (concept of waste to wealth) by providing job opportunities.

\section{CONCLUSION}

With the current awareness of the environmental challenges of fossil fuel and the demand for neat energy, biofuel is becoming popular, with attention shifting towards lignocellulosic materials as feedstock for biofuel production. From cost consideration and environmental safety, lignocellulosic bioethanol represents a potential pathway to the global provision of renewable and sustainable energy that can suffice the current challenges to biofuel provision in developing countries. Although the high cost of enzyme production has been identified as a challenge 
to the economic viability of lignocellulosic bioethanol, but there is hope that developing an efficient biosystem for SSF and CBP may help circumvent the challenge. The future of biofuel in developing countries is very bright as there are numerous bioresources that can help make this a reality.

Despite the abundant of natural resources in developing countries, it is obvious that most developing countries are not yet fully strategized to become major producer or exporter of biofuel or its feedstock. Therefore, it is important that government in developing countries should promote policies that can help local producers of biofuel and its feedstock, and not just foreign investors. For better biofuel technology development, it is high time that both private and public sectors invest in science and technology programmes or initiatives that will drive the design and development of techniques to ease biofuel production, this might be inform of

\section{REFERENCES}

Ab Rasid, N. S., Shamjuddin, A., Abdul Rahman, A. Z., and Amin, N. A. S. (2021). Recent Advances in green Pre-treatment Methods of Lignocellulosic Biomass for Enhanced Biofuel Production. J. Clean. Prod. 321, 129038. doi:10.1016/j. jclepro.2021.129038

Abila, N. (2014). Biofuels Adoption in Nigeria: Attaining a Balance in the Food, Fuel, Feed and Fibre Objectives. Renew. Sust. Energ. Rev. 35, 347-355. doi:10. 1016/j.rser.2014.04.011

Adewuyi, A. (2020). Challenges and Prospects of Renewable Energy in Nigeria: A Case of Bioethanol and Biodiesel Production. Energ. Rep. 6, 77-88. doi:10.1016/ j.egyr.2019.12.002

Alves, E. F., Bose, S. K., Francis, R. C., Colodette, J. L., Iakovlev, M., and Van Heiningen, A. (2010). Carbohydrate Composition of eucalyptus, Bagasse and Bamboo by a Combination of Methods. J. Carbohydr. Polym. 82, 1097-1101. doi:10.1016/j.carbpol.2010.06.038

Alvira, P., Tomás-Pejó, E., Ballesteros, M., and Negro, M. J. (2010). Pretreatment Technologies for an Efficient Bioethanol Production Process Based on Enzymatic Hydrolysis: a Review. Bioresour. Tech. 101, 4851-4861. doi:10. 1016/j.biortech.2009.11.093

Amin, F. R., Khalid, H., Zhang, H., Rahman, S. U., Zhang, R., Liu, G., et al. (2017). Pretreatment Methods of Lignocellulosic Biomass for Anaerobic Digestion. AMB Express 7, 72-12. doi:10.1186/s13568-017-0375-4

Amirta, R., Tanabe, T., Watanabe, T., Honda, Y., Kuwahara, M., and Watanabe, T. (2006). Methane Fermentation of Japanese Cedar wood Pretreated with a white Rot Fungus, Ceriporiopsis Subvermispora. J. Biotechnol. 123, 71-77. doi:10. 1016/j.jbiotec.2005.10.004

Badiei, M., Asim, N., Jahim, J. M., and Sopian, K. (2014). Comparison of Chemical Pretreatment Methods for Cellulosic Biomass. APCBEE Proced. 9, 170-174. doi:10.1016/j.apcbee.2014.01.030

Bai, X., Wang, G., Yu, Y., Wang, D., and Wang, Z. (2018). Changes in the Physicochemical Structure and Pyrolysis Characteristics of Wheat Straw after Rod-Milling Pretreatment. Bioresour. Tech. 250, 770-776. doi:10.1016/j. biortech.2017.11.085

Balat, M. (2007). Global Bio-Fuel Processing and Production Trends. Energy Exploration \& Exploitation 25, 195-218. doi:10.1260/014459807782009204

Barakat, A., De Vries, H., and Rouau, X. (2013). Dry Fractionation Process as an Important Step in Current and Future Lignocellulose Biorefineries: a Review. Bioresour. Tech. 134, 362-373. doi:10.1016/j.biortech.2013.01.169

Baruah, J., Nath, B. K., Sharma, R., Kumar, S., Deka, R. C., Baruah, D. C., et al. (2018). Recent Trends in the Pretreatment of Lignocellulosic Biomass for Value-Added Products. Front. Energ. Res. 6, 141. doi:10.3389/fenrg.2018.00141

Bautista, K., Unpaprom, Y., and Ramaraj, R. (2019). Bioethanol Production from Corn Stalk Juice Using Saccharomyces cerevisiae TISTR 5020. Energy Sourc. A: Recovery, Utilization, Environ. Effects 41, 1615-1621. doi:10.1080/15567036. 2018.1549136 providing research grants for research-based institutions. Production of lignocellulosic biomass should be encouraged either through contract farming with smallholders or cooperative institutions. In order to make it a win-win process for socio-economic growth, there is need for massive investments in chemical process research, agricultural research and social science research that will develop evidence base policy to help policy makers in developing appropriate guidelines for biofuel production in developing countries.

\section{AUTHOR CONTRIBUTIONS}

AA conceived the idea, executed the project and wrote the manuscript.

Beden, M. A., Zaini, M. a. A., and Abdullah, T. a. T. (2017). Ethanol Separation Using Sepabeads207 Adsorbent. Jurnal Teknologi 79. doi:10.11113/jt.v79.9900 Behera, S., Arora, R., Nandhagopal, N., and Kumar, S. (2014). Importance of Chemical Pretreatment for Bioconversion of Lignocellulosic Biomass. Renew. Sust. Energ. Rev. 36, 91-106. doi:10.1016/j.rser.2014.04.047

Belal, E. B. (2013). Bioethanol Production from rice Straw Residues. Braz. J. Microbiol. 44, 225-234. doi:10.1590/s1517-83822013000100033

Ben-Iwo, J., Manovic, V., and Longhurst, P. (2016). Biomass Resources and Biofuels Potential for the Production of Transportation Fuels in Nigeria. Renew. Sust. Energ. Rev. 63, 172-192. doi:10.1016/j.rser.2016.05.050

Bertilsson, M., Olofsson, K., and Lidén, G. (2009). Prefermentation Improves Xylose Utilization in Simultaneous Saccharification and Co-fermentation of Pretreated spruce. Biotechnol. Biofuels 2, 8-10. doi:10.1186/1754-6834-2-8

Betts, W. B., Dart, R. K., Ball, A. S., and Pedlar, S. L. (1991). "Biosynthesis and Structure of Lignocellulose," in Biosynthesis and Structure of lignocelluloseBiodegradation (Springer), 139-155. doi:10.1007/978-1-44713470-1_7

Bezerra, T. L., and Ragauskas, A. J. (2016). A Review of Sugarcane Bagasse for Second-Generation Bioethanol and Biopower Production. J. Biofuels Bioprod. 10, 634-647. doi:10.1002/bbb.1662

Bezerra, T. M. d. S., Bassan, J. C., Santos, V. T. d. O., Ferraz, A., and Monti, R. (2015). Covalent Immobilization of Laccase in green Coconut Fiber and Use in Clarification of Apple Juice. Process Biochem. 50, 417-423. doi:10.1016/j. procbio.2014.12.009

Bhatnagar, A., Kesari, K. K., and Shurpali, N. (2016). Multidisciplinary Approaches to Handling Wastes in Sugar Industries. J. Water Air Soil Pollut. 227, 1-30. doi:10.1007/s11270-015-2705-y

Börjesson, P., and Berndes, G. (2006). The Prospects for Willow Plantations for Wastewater Treatment in Sweden. J. Biomass Bioenergy 30, 428-438.

Bracco, S. (2015). Effectiveness of EU Biofuels Sustainability Criteria in the Context of Land Acquisitions in Africa. Renew. Sust. Energ. Rev. 50, 130-143. doi:10. 1016/j.rser.2015.05.006

Bušić, A., Marđetko, N., Kundas, S., Morzak, G., Belskaya, H., Ivančić Šantek, M., et al. (2018). Bioethanol Production from Renewable Raw Materials and its Separation and Purification: a Review. Food Technol. Biotechnol. 56, 289-311. doi:10.17113/ftb.56.03.18.5546

Cansino, J., Cardenete, M., González-Limón, J., and Román, R. (2013). Economic Impacts of Biofuels Deployment in Andalusia. Renew. Sust. Energ. Rev. 27, 274-282. doi:10.1016/j.rser.2013.06.006

Carminati, H. B., Milão, R. d. F. D., De Medeiros, J. L., and Araújo, O. d. Q. F. (2019). Bioenergy and Full Carbon Dioxide Sinking in Sugarcane-Biorefinery with post-combustion Capture and Storage: Techno-Economic Feasibility. Appl. Energ. 254, 113633. doi:10.1016/j.apenergy.2019.113633

Carrard, G., Koivula, A., Soderlund, H., and Beguin, P. (2000). Cellulosebinding Domains Promote Hydrolysis of Different Sites on Crystalline Cellulose. Proc. Natl. Acad. Sci. 97, 10342-10347. doi:10.1073/pnas. 160216697 
Carrasquillo-Flores, R., Käldström, M., Schüth, F., Dumesic, J. A., and Rinaldi, R. (2013). Mechanocatalytic Depolymerization of Dry (Ligno)cellulose as an Entry Process for High-Yield Production of Furfurals. ACS Catal. 3, 993-997. doi:10. $1021 / \operatorname{cs} 4001333$

Castoldi, R., Bracht, A., De Morais, G. R., Baesso, M. L., Correa, R. C. G., Peralta, R. A., et al. (2014). Biological Pretreatment of Eucalyptus Grandis Sawdust with white-rot Fungi: Study of Degradation Patterns and Saccharification Kinetics. Chem. Eng. J. 258, 240-246. doi:10.1016/j.cej.2014.07.090

Chang, V. S., and Holtzapple, M. T. (2000). "Fundamental Factors Affecting Biomass Enzymatic Reactivity," in Twenty-first Symposium on Biotechnology for Fuels and Chemicals (Springer), 5-37.

Chapple, C., Ladisch, M., and Meilan, R. (2007). Loosening Lignin's Grip on Biofuel Production. Nat. Biotechnol. 25, 746-748. doi:10.1038/nbt0707-746

Chen, H. (2014). "Chemical Composition and Structure of Natural Lignocellulose," in Biotechnology of Lignocellulose (Springer), 25-71. doi:10.1007/978-94-0076898-7_2

Chin, K., and H'ng, P. (2013). in A Real story of Bioethanol from Biomass: Malaysia Perspective. Biomass Now-Sustainable Growth And Use (Matovic, MDRijeka, Croatia: InTech Publisher), 329-346.

Chun, J., and Lee, J. H. (2020). Recent Progress on the Development of Engineered Silica Particles Derived from rice Husk. Sustainability 12, 10683. doi:10.3390/ su122410683

Chundawat, S. P. S., Balan, V., Sousa, L. D. c., and Dale, B. E. (2010). "Thermochemical Pretreatment of Lignocellulosic Biomass," in Bioalcohol Production (Elsevier), 24-72. doi:10.1533/9781845699611.1.24

Chung, D., Cha, M., Guss, A. M., and Westpheling, J. (2014). Direct Conversion of Plant Biomass to Ethanol by Engineered Caldicellulosiruptor Bescii. Proc. Natl. Acad. Sci. 111, 8931-8936. doi:10.1073/pnas.1402210111

Cianchetta, S., Di Maggio, B., Burzi, P. L., and Galletti, S. (2014). Evaluation of Selected white-rot Fungal Isolates for Improving the Sugar Yield from Wheat Straw. J. Appl. Biochem. 173, 609-623. doi:10.1007/s12010-0140869-3

Clauser, N. M., González, G., Mendieta, C. M., Kruyeniski, J., Area, M. C., and Vallejos, M. E. (2021). Biomass Waste as Sustainable Raw Material for Energy and Fuels. Sustainability 13, 794. doi:10.3390/su13020794

Corbin, K. R., Byrt, C. S., Bauer, S., Debolt, S., Chambers, D., Holtum, J. A. M., et al. (2015). Prospecting for Energy-Rich Renewable Raw Materials: Agave Leaf Case Study. PLoS One 10, e0135382. doi:10.1371/journal.pone.0135382

Cristina dos Santos Lima, F., Luiz Honorato da Silva, F., Palmeira Gomes, J., and Mariano da Silva Neto, J. (2012). Chemical Composition of the Cashew Apple Bagasse and Potential Use for Ethanol Production. Aces 02, 519-523. doi:10. 4236/aces.2012.24064

Cui, M., Yuan, Z., Zhi, X., Wei, L., and Shen, J. (2010). Biohydrogen Production from poplar Leaves Pretreated by Different Methods Using Anaerobic Mixed Bacteria. Int. J. Hydrogen Energ. 35, 4041-4047. doi:10.1016/j.ijhydene.2010. 02.035

Cunha, J. T., Romaní, A., Inokuma, K., Johansson, B., Hasunuma, T., Kondo, A., et al. (2020). Consolidated Bioprocessing of Corn Cob-Derived Hemicellulose: Engineered Industrial Saccharomyces cerevisiae as Efficient Whole Cell Biocatalysts. Biotechnol. Biofuels 13, 1-15. doi:10.1186/s13068-020-01780-2

Da Costa, J. A., Marques Jr., J. E., Jr, Gonçalves, L. R. B., and Rocha, M. V. P. (2015). Enhanced Enzymatic Hydrolysis and Ethanol Production from Cashew Apple Bagasse Pretreated with Alkaline Hydrogen Peroxide. Bioresour. Tech. 179, 249-259. doi:10.1016/j.biortech.2014.11.010

de C. Merschmann, P. R., Szklo, A. S., and Schaeffer, R. (2016). Technical Potential and Abatement Costs Associated with the Use of Process Emissions from Sugarcane Ethanol Distilleries for EOR in Offshore fields in Brazil. Int. J. Greenhouse Gas Control. 52, 270-292. doi:10.1016/j.ijggc.2016.07.007

de Souza Noel Simas Barbosa, L., Hytönen, E., and Vainikka, P. (2017). Carbon Mass Balance in Sugarcane Biorefineries in Brazil for Evaluating Carbon Capture and Utilization Opportunities. Biomass and Bioenergy 105, 351-363. doi:10.1016/j.biombioe.2017.07.015

Demirbas, A., and Demirbas, M. F. (2010). Algae Technology. J. Energ. Edu. Sci. Tech. B-Social Educ. Stud. 2, 75-96. doi:10.1007/978-1-84996-050-2_4

Devrije, T., De Haas, G., Tan, G., Keijsers, E., and Claassen, P. (2002). Pretreatment of Miscanthus for Hydrogen Production by Thermotoga Elfii. Int. J. Hydrogen Energ. 27, 1381-1390. doi:10.1016/s0360-3199(02)00124-6
Dey, P., Pal, P., Kevin, J. D., and Das, D. B. (2020). Lignocellulosic Bioethanol Production: Prospects of Emerging Membrane Technologies to Improve the Process - a Critical Review. J. Rev. Chem. Eng. 36, 333-367. doi:10.1515/revce2018-0014

Dimos, K., Paschos, T., Louloudi, A., Kalogiannis, K., Lappas, A., Papayannakos, N., et al. (2019). Effect of Various Pretreatment Methods on Bioethanol Production from Cotton Stalks. Fermentation 5. doi:10.3390/ fermentation5010005

Donaldson, L. A., Wong, K. K. Y., and Mackie, K. L. (1988). Ultrastructure of Steam-Exploded wood. Wood Sci.Technol. 22, 103-114. doi:10.1007/ bf00355846

Doran-Peterson, J., Jangid, A., Brandon, S., Decrescenzo-Henriksen, E., Dien, B., and Ingram, L. (2010). J Methods in Molecular Biology. California: Humana Press.Biofuels: Methods and Protocols

Druzhinina, I. S., Shelest, E., and Kubicek, C. P. (2012). Novel Traits ofTrichodermapredicted through the Analysis of its Secretome. FEMS Microbiol. Lett. 337, 1-9. doi:10.1111/j.1574-6968.2012.02665.x

Du, H., Liu, C., Zhang, Y., Yu, G., Si, C., Li, B., et al. (2016). Preparation and Characterization of Functional Cellulose Nanofibrils via Formic Acid Hydrolysis Pretreatment and the Followed High-Pressure Homogenization. J. Ind. Crops Prod. 94, 736-745. doi:10.1016/j.indcrop.2016.09.059

Elumalai, S., Agarwal, B., Runge, T. M., and Sangwan, R. S. (2018). “Advances in Transformation of Lignocellulosic Biomass to Carbohydrate-Derived Fuel Precursors," in Biorefining of Biomass to Biofuels (Springer), 87-116. doi:10. 1007/978-3-319-67678-4_4

Forough, N., Dzulkefly, K. A., Norhafizah, A., Nazila, M., and Zamiri, R. (20132013). Biological Pretreatment of Rubberwood with Ceriporiopsis Subvermispora for Enzymatic Hydrolysis and Bioethanol Production. J. Biomed. Res. Int.

Galbe, M., and Zacchi, G. (2007). Pretreatment of Lignocellulosic Materials for Efficient Bioethanol Production. Adv. Biochem. Eng. Biotechnol. 108, 41-65. doi:10.1007/10_2007_070

Gasparatos, A., Von Maltitz, G. P., Johnson, F. X., Lee, L., Mathai, M., Puppim de Oliveira, J. A., et al. (2015). Biofuels in Sub-sahara Africa: Drivers, Impacts and Priority Policy Areas. Renew. Sust. Energ. Rev. 45, 879-901. doi:10.1016/j.rser. 2015.02.006

Giovannetti, G., and Ticci, E. (2016). Determinants of Biofuel-Oriented Land Acquisitions in Sub-saharan Africa. Renew. Sust. Energ. Rev. 54, 678-687. doi:10.1016/j.rser.2015.10.008

Gottumukkala, L. D., Haigh, K., Collard, F.-X., Van Rensburg, E., and Görgens, J. (2016). Opportunities and Prospects of Biorefinery-Based Valorisation of Pulp and Paper Sludge. Bioresour. Tech. 215, 37-49. doi:10.1016/j.biortech.2016. 04.015

Grohmann, K., Torget, R., and Himmel, M. (1986). “Optimization of Dilute Acid Pretreatment of Biomass," in Biotechnology And Bioengineering Symposium), 59-80.

Gu, B.-J., Wang, J., Wolcott, M. P., and Ganjyal, G. M. (2018). Increased Sugar Yield from Pre-milled Douglas-fir forest Residuals with Lower Energy Consumption by Using Planetary ball Milling. Bioresour. Tech. 251, 93-98. doi:10.1016/j.biortech.2017.11.103

Guo, Y., and Rockstraw, D. A. (2007). Activated Carbons Prepared from rice hull by One-step Phosphoric Acid Activation. J. Microporous Mesoporous Mater. 100, 12-19. doi:10.1016/j.micromeso.2006.10.006

Hamelinck, C. N., Hooijdonk, G. v., and Faaij, A. P. (2005). Ethanol from Lignocellulosic Biomass: Techno-Economic Performance in Short-, Middleand Long-Term. Biomass and Bioenergy 28, 384-410. doi:10.1016/j.biombioe. 2004.09.002

Harris, D., and Debolt, S. (2010). Synthesis, Regulation and Utilization of Lignocellulosic Biomass. Plant Biotechnol. J. 8, 244-262. doi:10.1111/j.14677652.2009.00481.x

Headey, D., and Fan, S. (2008). Anatomy of a Crisis: the Causes and Consequences of Surging Food Prices. J. Agric. Econ. 39, 375-391. doi:10.1111/j.1574-0862. 2008.00345.x

Hick, S. M., Griebel, C., Restrepo, D. T., Truitt, J. H., Buker, E. J., Bylda, C., et al. (2010). Mechanocatalysis for Biomass-Derived Chemicals and Fuels. Green. Chem. 12, 468-474. doi:10.1039/b923079c

Holtzapple, M. T., Lundeen, J. E., Sturgis, R., Lewis, J. E., and Dale, B. E. (1992). Pretreatment of Lignocellulosic Municipal Solid Waste by Ammonia Fiber 
Explosion (AFEX). Appl. Biochem. Biotechnol. 34-35, 5-21. doi:10.1007/ bf02920530

Hon, D., Frollini, E., Leão, A., Mattoso, L. J. E. F., and Mattoso, A. L. Y. L. (2000). Natural Polymers and Agrofibers Composites, 1-14.

Hossain, S. S., Mathur, L., and Roy, P. K. (2018). Rice Husk/rice Husk Ash as an Alternative Source of Silica in Ceramics: A Review. J. Asian Ceram. Societies 6, 299-313. doi:10.1080/21870764.2018.1539210

Howard, R. L., Abotsi, E., Jansen, v. R. E. L., and Howard, S. (2003). Lignocellulose Biotechnology: Issues of Bioconversion and Enzyme Production. Afr. J. Biotechnol. 2, 602-619. doi:10.5897/ajb2003.000-1115

Hwangbo, M., Tran, J. L., and Chu, K.-H. (2019). Effective One-step Saccharification of Lignocellulosic Biomass Using Magnetite-Biocatalysts Containing Saccharifying Enzymes. Sci. Total Environ. 647, 806-813. doi:10. 1016/j.scitotenv.2018.08.066

Ibitoyea, S., Adeguna, I., Omoniyia, P., Ogedengbeb, T., and Alabia, O. (2020). Journal of Bioresources and Bioproducts. J. Bioresources Bioproducts 5, 220-229.

Isikgor, F. H., and Becer, C. R. (2015). Lignocellulosic Biomass: a Sustainable Platform for the Production of Bio-Based Chemicals and Polymers. Polym. Chem. 6, 4497-4559. doi:10.1039/c5py00263j

Jaffar, M., Pang, Y., Yuan, H., Zou, D., Liu, Y., Zhu, B., et al. (2016). Wheat Straw Pretreatment with $\mathrm{KOH}$ for Enhancing Biomethane Production and Fertilizer Value in Anaerobic Digestion. Chin. J. Chem. Eng. 24, 404-409. doi:10.1016/j. cjche.2015.11.005

Jeon, Y. J., Xun, Z., and Rogers, P. L. (2010). Comparative Evaluations of Cellulosic Raw Materials for Second Generation Bioethanol Production. J. Lett. Appl. Microbiol. 51, 518-524. doi:10.1111/j.1472-765x.2010.02923.x

Jeong, S.-Y., and Lee, J.-W. (2016). Optimization of Pretreatment Condition for Ethanol Production from Oxalic Acid Pretreated Biomass by Response Surface Methodology. Ind. Crops Prod. 79, 1-6. doi:10.1016/j.indcrop.2015.10.036

Jeswani, H. K., Chilvers, A., and Azapagic, A. (2020). Environmental Sustainability of Biofuels: a Review. Proc. R. Soc. A. 476, 20200351. doi:10.1098/rspa.2020.0351

Jin, M., Gunawan, C., Balan, V., and Dale, B. E. (2012). Consolidated Bioprocessing (CBP) of AFEX-Pretreated Corn stover for Ethanol Production Using Clostridium Phytofermentans at a High Solids Loading. Biotechnol. Bioeng. 109, 1929-1936. doi:10.1002/bit.24458

Jørgensen, H. (2009). Effect of Nutrients on Fermentation of Pretreated Wheat Straw at Very High Dry Matter Content by Saccharomyces cerevisiae. J. Appl. Biochem. Biotechnol. 153, 44-57.

Jung, Y. H., Park, H. M., and Kim, K. H. (2015). Whole Slurry Saccharification and Fermentation of Maleic Acid-Pretreated rice Straw for Ethanol Production. Bioproc. Biosyst Eng 38, 1639-1644. doi:10.1007/s00449-015-1405-8

Kahlon, T. S. (2009). "Rice Bran: Production, Composition, Functionality and Food Applications, Physiological Benefits," in Fiber Ingredients (London: CRC Press), 319-336.

Kamiya, N., Matsushita, Y., Hanaki, M., Nakashima, K., Narita, M., Goto, M., et al. (2008). Enzymatic In Situ Saccharification of Cellulose in Aqueous-Ionic Liquid media. Biotechnol. Lett. 30, 1037-1040. doi:10. 1007/s10529-008-9638-0

Kärcher, M. A., Iqbal, Y., Lewandowski, I., and Senn, T. (2015). Comparing the Performance of Miscanthus X Giganteus and Wheat Straw Biomass in Sulfuric Acid Based Pretreatment. Bioresour. Technol. 180, 360-364. doi:10.1016/j. biortech.2014.12.107

Karmakar, A., Karmakar, S., and Mukherjee, S. (2010). Properties of Various Plants and Animals Feedstocks for Biodiesel Production. Bioresour. Tech. 101, 7201-7210. doi:10.1016/j.biortech.2010.04.079

Kavalopoulos, M., Stoumpou, V., Christofi, A., Mai, S., Barampouti, E. M., Moustakas, K., et al. (2021). Sustainable Valorisation Pathways Mitigating Environmental Pollution from Brewers' Spent Grains. Environ. Pollut. 270, 116069. doi:10.1016/j.envpol.2020.116069

Khaleghian, H., Molaverdi, M., and Karimi, K. (2017). Silica Removal from rice Straw to Improve its Hydrolysis and Ethanol Production. Ind. Eng. Chem. Res. 56, 9793-9798. doi:10.1021/acs.iecr.7b02830

Kim, I., Seo, Y. H., Kim, G.-Y., and Han, J.-I. (2015). Co-production of Bioethanol and Biodiesel from Corn stover Pretreated with Nitric Acid. Fuel 143, 285-289. doi:10.1016/j.fuel.2014.11.031
Kim, J.-W., Kim, K. S., Lee, J.-S., Park, S. M., Cho, H.-Y., Park, J. C., et al. (2011). Two-stage Pretreatment of rice Straw Using Aqueous Ammonia and Dilute Acid. Bioresour. Tech. 102, 8992-8999. doi:10.1016/j.biortech.2011.06.068

Kim, J. S., Lee, Y. Y., and Kim, T. H. (2016). A Review on Alkaline Pretreatment Technology for Bioconversion of Lignocellulosic Biomass. Bioresour. Tech. 199, 42-48. doi:10.1016/j.biortech.2015.08.085

Kim, S. (20182018). Enhancing Bioethanol Productivity Using Alkali-Pretreated Empty palm Fruit bunch Fiber Hydrolysate. J. Biomed. Research International. doi:10.1155/2018/5272935

Kim, S., and Holtzapple, M. T. (2006). Effect of Structural Features on Enzyme Digestibility of Corn stover. Bioresour. Tech. 97, 583-591. doi:10.1016/j. biortech.2005.03.040

Kim, T. H., Jeon, Y. J., Oh, K. K., and Kim, T. H. (2013). Production of Furfural and Cellulose from Barley Straw Using Acidified Zinc Chloride. Korean J. Chem. Eng. 30, 1339-1346. doi:10.1007/s11814-013-0068-x

Kim, T. H., Oh, K. K., Ryu, H. J., Lee, K.-H., and Kim, T. H. (2014). Hydrolysis of Hemicellulose from Barley Straw and Enhanced Enzymatic Saccharification of Cellulose Using Acidified Zinc Chloride. Renew. Energ. 65, 56-63. doi:10.1016/ j.renene.2013.07.011

Knauf, M., and Moniruzzaman, M. (2004). Lignocellulosic Biomass Processing: a Perspective. J. Int. sugar J. 106, 147-150.

Koh, L. P., and Ghazoul, J. (2008). Biofuels, Biodiversity, and People: Understanding the Conflicts and Finding Opportunities. Biol. Conservation 141, 2450-2460. doi:10.1016/j.biocon.2008.08.005

Koul, D., Shukla, G., Panwar, P., and Chakravarty, S. (2011). Status of Soil Carbon Sequestration under Different Land Use Systems in Terai Zone of West Bengal. J. Environ. We: Int. J. Sci. Tech. 6, 95-100.

Kousoulidou, M., and Lonza, L. (2016). Biofuels in Aviation: Fuel Demand and CO2 Emissions Evolution in Europe toward 2030. Transportation Res. D: Transport Environ. 46, 166-181. doi:10.1016/j.trd.2016.03.018

Kricka, W., James, T. C., Fitzpatrick, J., and Bond, U. (2015). Engineering Saccharomyces Pastorianus for the Co-utilisation of Xylose and Cellulose from Biomass. Microb. Cel Fact 14, 61-11. doi:10.1186/s12934-015-0242-4

Kristensen, J. B. (2008). Enzymatic Hydrolysis of Lignocellulose. Substrate Interactions and High. Frederiksberg: Forest \& Landscape Research.

Kucharska, K., Słupek, E., Cieśliński, H., and Kamiński, M. (2020). Advantageous Conditions of Saccharification of Lignocellulosic Biomass for Biofuels Generation via Fermentation Processes. Chem. Pap. 74, 1199-1209. doi:10. 1007/s11696-019-00960-1

Kumar, D., and Murthy, G. S. (2011). Impact of Pretreatment and Downstream Processing Technologies on Economics and Energy in Cellulosic Ethanol Production. Biotechnol. Biofuels 4, 27-19. doi:10.1186/1754-6834-4-27

Kumar, R., Sharma, R. K., and Singh, A. P. (2017). Cellulose Based Grafted Biosorbents - Journey from Lignocellulose Biomass to Toxic Metal Ions Sorption Applications - A Review. J. Mol. Liquids 232, 62-93. doi:10.1016/j. molliq.2017.02.050

Kumar, R., Singh, S., and Singh, O. V. (2008). Bioconversion of Lignocellulosic Biomass: Biochemical and Molecular Perspectives. J. Ind. Microbiol. 35, 377-391. doi:10.1007/s10295-008-0327-8

Lalak, J., Kasprzycka, A., Martyniak, D., and Tys, J. (2016). Effect of Biological Pretreatment of Agropyron Elongatum 'BAMAR' on Biogas Production by Anaerobic Digestion. Bioresour. Tech. 200, 194-200. doi:10.1016/j.biortech.2015. 10.022

Lee, W.-C., and Kuan, W.-C. (2015). Miscanthusas Cellulosic Biomass for Bioethanol Production. Biotechnol. J. 10, 840-854. doi:10.1002/biot.201400704

Li, C., Knierim, B., Manisseri, C., Arora, R., Scheller, H. V., Auer, M., et al. (2010). Comparison of Dilute Acid and Ionic Liquid Pretreatment of Switchgrass: Biomass Recalcitrance, Delignification and Enzymatic Saccharification. Bioresour. Tech. 101, 4900-4906. doi:10.1016/j.biortech.2009.10.066

Liu, K., Li, S., Yu, H., and Liu, Z. (2011). To the Stars. Nature 470, 134. doi:10.1038/ 470134a

Liu, S., Li, X., Wu, S., He, J., Pang, C., Deng, Y., et al. (2014). Fungal Pretreatment by Phanerochaete Chrysosporium for Enhancement of Biogas Production from Corn stover Silage. Appl. Biochem. Biotechnol. 174, 1907-1918. doi:10.1007/ s12010-014-1185-7

Liu, Y., Wang, J., Barth, J. C., Welsch, K. R., Mcintyre, V., and Wolcott, M. P. (2020). Effects of Multi-Stage Milling Method on the Energy Consumption of 
Comminuting forest Residuals. Ind. Crops Prod. 145, 111955. doi:10.1016/j. indcrop.2019.111955

Liu, Z.-H., and Chen, H.-Z. (2016). Simultaneous Saccharification and Cofermentation for Improving the Xylose Utilization of Steam Exploded Corn stover at High Solid Loading. Bioresour. Tech. 201, 15-26. doi:10.1016/j. biortech.2015.11.023

Louime, C., Onokpise, O., and Vasanthaiah, H. (2011). Insights into the Catalytic Mechanism of Cellulose Hydrolysis by Cytophaga Hutchinsonii. J. Curr. Sci. $100,1486-1488$.

Louime, C., and Uckelmann, H. (2008). Potential and Prospects of Cellulosic Ethanol in the World. J. Curr. Sci. 94.

Luque, L., Oudenhoven, S., Westerhof, R., Van Rossum, G., Berruti, F., Kersten, S., et al. (2016). Comparison of Ethanol Production from Corn Cobs and Switchgrass Following a Pyrolysis-Based Biorefinery Approach. Biotechnol. Biofuels 9, 1-14. doi:10.1186/s13068-016-0661-4

Lynd, L. R., Weimer, P. J., Van Zyl, W. H., Pretorius, I. S., and Reviews, M. B. (2002). Microbial Cellulose Utilization: Fundamentals and Biotechnology. Microbiol. Mol. Biol. Rev. 66, 506-577. doi:10.1128/mmbr.66.3.506-577.2002

Mallen, E., and Najdanovic-Visak, V. (2018). Brewers' Spent Grains: Drying Kinetics and Biodiesel Production. Bioresour. Tech. Rep. 1, 16-23. doi:10. 1016/j.biteb.2018.01.005

Malode, S. J., Prabhu, K. K., Mascarenhas, R. J., Shetti, N. P., and Aminabhavi, T. M. (2021). Recent Advances and Viability in Biofuel Production. Energy Convers. Manag. X 10, 100070. doi:10.1016/j.ecmx.2020.100070

Manzanares, P. (2010). "Integrated Hydrolysis, Fermentation and Co-fermentation of Lignocellulosic Biomass," in Bioalcohol Production (Elsevier), 205-223. doi:10.1533/9781845699611.3.205

Martinez, D., Larrondo, L. F., Putnam, N., Gelpke, M. D. S., Huang, K., Chapman, J., et al. (2004). Genome Sequence of the Lignocellulose Degrading Fungus Phanerochaete Chrysosporium Strain RP78. Nat. Biotechnol. 22, 695-700. doi:10.1038/nbt967

Mattam, A. J., Kuila, A., Suralikerimath, N., Choudary, N., Rao, P. V., and Velankar, H. R. (2016). Cellulolytic Enzyme Expression and Simultaneous Conversion of Lignocellulosic Sugars into Ethanol and Xylitol by a New Candida tropicalis Strain. Biotechnol. Biofuels 9, 1-12. doi:10.1186/s13068016-0575-1

Maurya, D. P., Singla, A., and Negi, S. (2015). An Overview of Key Pretreatment Processes for Biological Conversion of Lignocellulosic Biomass to Bioethanol. 3 Biotech. 5, 597-609. doi:10.1007/s13205-015-0279-4

Mckendry, P. (2002). Energy Production from Biomass (Part 1): Overview of Biomass. Bioresour. Tech. 83, 37-46. doi:10.1016/s0960-8524(01)00118-3

Mcmillan, J. D. (1994). Pretreatment of Lignocellulosic Biomass.

Meine, N., Rinaldi, R., and Schüth, F. (2012). Solvent-Free Catalytic Depolymerization of Cellulose to Water-Soluble Oligosaccharides. ChemSusChem 5, 1449-1454. doi:10.1002/cssc.201100770

Menon, V., and Rao, M. (2012). Trends in Bioconversion of Lignocellulose: Biofuels, Platform Chemicals \& Biorefinery Concept. Prog. Energ. Combustion Sci. 38, 522-550. doi:10.1016/j.pecs.2012.02.002

Mezule, L., Strods, M., and Dalecka, B. (2016). Influence of Mechanical Pre-treatment on Fermentable Sugar Production from Lignocellulosic Biomass. J. Agron. Res. 14, 1427-1434.

Michelin, M., Ruíz, H. A., Silva, D. P. D., Ruzene, D. S., Teixeira, J., and Polizeli, M. D. L. (2015). Cellulose from Lignocellulosic Waste.

Mishra, V., and Jana, A. K. (2017). Fungal Pretreatment of Sweet Sorghum Bagasse with Combined CuSO4-Gallic Acid Supplement for Improvement in Lignin Degradation, Selectivity, and Enzymatic Saccharification. Appl. Biochem. Biotechnol. 183, 200-217. doi:10.1007/s12010-017-2439-y

Mkhize, T., Mthembu, L. D., Gupta, R., Kaur, A., Kuhad, R. C., Reddy, P., et al. (2016). Enzymatic Saccharification of Acid/alkali Pre-treated, Mill-Run, and Depithed Sugarcane Bagasse. J. Bioresources 11, 6267-6285. doi:10.15376/ biores.11.3.6267-6285

Mosihuzzaman, M., Theander, O., and Åman, P. (1982). Analysis of Carbohydrates in the Jute Plant (Corchorus Capsularis). J. Sci. Food 33, 1207-1212. doi:10. $1002 /$ jsfa. 2740331206

Mustafa, A. M., Poulsen, T. G., and Sheng, K. (2016). Fungal Pretreatment of rice Straw with Pleurotus Ostreatus and Trichoderma Reesei to Enhance Methane Production under Solid-State Anaerobic Digestion. Appl. Energ. 180, 661-671. doi:10.1016/j.apenergy.2016.07.135
Nair, R. B., Lundin, M., Brandberg, T., Lennartsson, P. R., and Taherzadeh, M. J. (2015). Dilute Phosphoric Acid Pretreatment of Wheat Bran for Enzymatic Hydrolysis and Subsequent Ethanol Production by Edible Fungi Neurospora Intermedia. Ind. Crops Prod. 69, 314-323. doi:10.1016/ j.indcrop.2015.02.038

Navarro, R. R., Otsuka, Y., Nojiri, M., Ishizuka, S., Nakamura, M., Shikinaka, K., et al. (2018). Simultaneous Enzymatic Saccharification and Comminution for the Valorization of Lignocellulosic Biomass toward Natural Products. BMC Biotechnol. 18, 79-11. doi:10.1186/s12896-018-0487-1

Nissilä, M. E., Lay, C.-H., and Puhakka, J. A. (2014). Dark Fermentative Hydrogen Production from Lignocellulosic Hydrolyzates-A Review. J. Biomass Bioenergy $67,145-159$.

Nwakaire, J., Ezeoha, S. L., and Ugwuishiwu, B. (2013). Production of Cellulosic Ethanol from wood Sawdust. Agric. Eng. Int. CIGR J. 15, 136-140.

O. Akinola, T., Erkurt, E. A., and A. Erkurt, E. (2014). Bio-Ethanol Production from Cornstalk Containing Wastewater. J. Environ. Sci. Eng. Technol. 2, 31-34. doi:10.12974/2311-8741.2014.02.02.1

Ohimain, E. I. (2013). Can the Nigerian Biofuel Policy and Incentives (2007) Transform Nigeria into a Biofuel Economy? Energy Policy 54, 352-359. doi:10. 1016/j.enpol.2012.11.051

Okano, K., Kitagawa, M., Sasaki, Y., and Watanabe, T. (2005). Conversion of Japanese Red Cedar (Cryptomeria Japonica) into a Feed for Ruminants by white-rot Basidiomycetes. Anim. Feed Sci. Tech. 120, 235-243. doi:10.1016/j. anifeedsci.2005.02.023

Olofsson, K., Palmqvist, B., and Lidén, G. (2010). Improving Simultaneous Saccharification and Co-fermentation of Pretreated Wheat Straw Using Both Enzyme and Substrate Feeding. Biotechnol. Biofuels 3, 17-19. doi:10.1186/17546834-3-17

Olofsson, K., Rudolf, A., and Lidén, G. (2008). Designing Simultaneous Saccharification and Fermentation for Improved Xylose Conversion by a Recombinant Strain of Saccharomyces cerevisiae. J. Biotechnol. 134, 112-120. doi:10.1016/j.jbiotec.2008.01.004

Olson, D. G., Mcbride, J. E., Joe Shaw, A., and Lynd, L. R. (2012). Recent Progress in Consolidated Bioprocessing. Curr. Opin. Biotechnol. 23, 396-405. doi:10.1016/j. copbio.2011.11.026

Organization, A. (2008). The State of Food and Agriculture 2008: Biofuels: Prospects, Risks and Opportunities. New York, NY: Food \& Agriculture Org.

Pan, X., Gilkes, N., and Saddler, J. N. (2006). Effect of Acetyl Groups on Enzymatic Hydrolysis of Cellulosic Substrates.doi:10.1515/hf.2006.062

Patel, A., Mikes, F., Bühler, S., and Matsakas, L. (2018). Valorization of Brewers' Spent Grain for the Production of Lipids by Oleaginous Yeast. Molecules 23, 3052. doi:10.3390/molecules23123052

Pattnaik, F., Tripathi, S., Patra, B. R., Nanda, S., Kumar, V., Dalai, A. K., et al. (2021). Catalytic Conversion of Lignocellulosic Polysaccharides to Commodity Biochemicals: a Review. Environ. Chem. Lett. 19, 4119-4136. doi:10.1007/ s10311-021-01284-x

Philippidis, G. P. (2018). "Cellulose Bioconversion Technology," in Handbook on Bioethanol (London: Routledge), 253-285. doi:10.1201/9780203752456-12

Pielhop, T., Amgarten, J., Von Rohr, P. R., and Studer, M. H. (2016). Steam Explosion Pretreatment of Softwood: the Effect of the Explosive Decompression on Enzymatic Digestibility. Biotechnol. Biofuels 9, 1-13. doi:10.1186/s13068016-0567-1

Pradhan, A., Ali, S., and Dash, R. (2013). Biomass Gasification by the Use of rice Husk Gasifier. J. Spec. Issue. Int. J. Adv. Comp. Theor. Eng. 2, 14-17.

Prasad, S., Singh, A., and Joshi, H. C. (2007). Ethanol as an Alternative Fuel from Agricultural, Industrial and Urban Residues. J. Resour. Conserv. 50, 1-39. doi:10.1016/j.resconrec.2006.05.007

Rabemanolontsoa, H., and Saka, S. (2013). Comparative Study on Chemical Composition of Various Biomass Species. RSC Adv. 3, 3946-3956. doi:10. 1039/c3ra22958k

Rafieenia, R., Lavagnolo, M. C., and Pivato, A. (2018). Pre-treatment Technologies for Dark Fermentative Hydrogen Production: Current Advances and Future Directions. Waste Manag. 71, 734-748. doi:10.1016/j.wasman.2017.05.024

Reguant, J., and Rinaudo, M. J. L. P. N. S. (2000). Modifications, Applications. Fibres Lignocellulosiques. En Iniciation á la Chimie et á la Physico-Chimie Macromoleculares, 13.

Rocha, M. V. P., Rodrigues, T. H. S., De Albuquerque, T. L., Gonçalves, L. R. B., and De Macedo, G. R. (2014). Evaluation of Dilute Acid Pretreatment on Cashew 
Apple Bagasse for Ethanol and Xylitol Production. Chem. Eng. J. 243, 234-243. doi:10.1016/j.cej.2013.12.099

Rodrigues, T. H. S., Rocha, M. V. P., De Macedo, G. R., and Gonçalves, L. R. (2011). Ethanol Production from Cashew Apple Bagasse: Improvement of Enzymatic Hydrolysis by Microwave-Assisted Alkali Pretreatment. J. Appl. Biochem. Biotechnol. 164, 929-943. doi:10.1007/s12010-011-9185-3

Rojas-Chamorro, J. A., Cara, C., Romero, I., Ruiz, E., Romero-García, J. M., Mussatto, S. I., et al. (2018). Ethanol Production from Brewers' Spent Grain Pretreated by Dilute Phosphoric Acid. Energy Fuels 32, 5226-5233. doi:10.1021/ acs.energyfuels.8b00343

Rubio, M., Tortosa, J. F., Quesada, J., Gómez, D., and Bioenergy (1998). Fractionation of Lignocellulosics. Solubilization of Corn Stalk Hemicelluloses by Autohydrolysis in Aqueous Medium. J. Biomass 15, 483-491. doi:10.1016/s0961-9534(98)00054-3

Ruiz, E., Cara, C., Ballesteros, M., Manzanares, P., Ballesteros, I., and Castro, E. (2006). Ethanol Production from Pretreated Olive Tree wood and sunflower Stalks by an SSF Process. Abab 130, 631-643. doi:10.1385/abab:130:1:631

Sadh, P. K., Duhan, S., and Duhan, J. S. (2018). Agro-industrial Wastes and Their Utilization Using Solid State Fermentation: a Review. Bioresour. Bioproc. 5, 1-15. doi:10.1186/s40643-017-0187-z

Saha, B. C. (2005). Enzymes as Biocatalysts for Conversion of Lignocellulosic Biomass to Fermentable Sugars. J. Handbook Industrial Biocatalysis, 1-12. doi:10.1201/9781420027969.ch24

Sahlan, M., Yulistiono, L., Sasongko, A., Khayrani, A. C., Lischer, K., and Pratami, D. K. (2021). Ethanol Recovery from Propolis Production Waste Using Adsorption Distillation Method. Int. J. App Pharm. 13, 13-17. doi:10.22159/ ijap.2021.v13s2.03

Sahoo, D., Ummalyma, S. B., Okram, A. K., Pandey, A., Sankar, M., and Sukumaran, R. K. (2018). Effect of Dilute Acid Pretreatment of Wild rice Grass (Zizania Latifolia) from Loktak Lake for Enzymatic Hydrolysis. Bioresour. Tech. 253, 252-255. doi:10.1016/j.biortech.2018.01.048

Satlewal, A., Agrawal, R., Bhagia, S., Das, P., and Ragauskas, A. J. (2018). Rice Straw as a Feedstock for Biofuels: Availability, Recalcitrance, and Chemical Properties. Biofuels, Bioprod. Bioref. 12, 83-107. doi:10.1002/bbb.1818

Scheller, H. V., and Ulvskov, P. (2010). Hemicelluloses. Annu. Rev. Plant Biol. 61, 263-289. doi:10.1146/annurev-arplant-042809-112315

Sekhon, J., Maurer, D., Wang, T., Jung, S., and Rosentrater, K. (2018). Ethanol Production by Soy Fiber Treatment and Simultaneous Saccharification and Cofermentation in an Integrated Corn-Soy Biorefinery. Fermentation 4, 35. doi:10. 3390/fermentation 4020035

Shallom, D., and Shoham, Y. (2003). Microbial Hemicellulases. Curr. Opin. Microbiol. 6, 219-228. doi:10.1016/s1369-5274(03)00056-0

Shao, X., Jin, M., Guseva, A., Liu, C., Balan, V., Hogsett, D., et al. (2011). Conversion for Avicel and AFEX Pretreated Corn stover by Clostridium Thermocellum and Simultaneous Saccharification and Fermentation: Insights into Microbial Conversion of Pretreated Cellulosic Biomass. Bioresour. Tech. 102, 8040-8045. doi:10.1016/j.biortech.2011.05.021

Shaw, A. J., Podkaminer, K. K., Desai, S. G., Bardsley, J. S., Rogers, S. R., Thorne, P. G., et al. (2008). Metabolic Engineering of a Thermophilic Bacterium to Produce Ethanol at High Yield. Proc. Natl. Acad. Sci. 105, 13769-13774. doi:10.1073/pnas.0801266105

Shen, J., Zhao, C., Liu, G., and Chen, C. (2017). Enhancing the Performance on Anaerobic Digestion of Vinegar Residue by Sodium Hydroxide Pretreatment. Waste Biomass Valor. 8, 1119-1126. doi:10.1007/s12649-016-9666-2

Shetty, D. J., Kshirsagar, P., Tapadia-Maheshwari, S., Lanjekar, V., Singh, S. K., and Dhakephalkar, P. K. (2017). Alkali Pretreatment at Ambient Temperature: A Promising Method to Enhance Biomethanation of rice Straw. Bioresour. Tech. 226, 80-88. doi:10.1016/j.biortech.2016.12.003

Shrotri, A., Lambert, L. K., Tanksale, A., and Beltramini, J. (2013). Mechanical Depolymerisation of Acidulated Cellulose: Understanding the Solubility of High Molecular Weight Oligomers. Green. Chem. 15, 2761-2768. doi:10.1039/ c3gc40945g

Sills, D. L., and Gossett, J. M. (2011). Assessment of Commercial Hemicellulases for Saccharification of Alkaline Pretreated Perennial Biomass. Bioresour. Tech. 102, 1389-1398. doi:10.1016/j.biortech.2010.09.035

Sindhu, R., Binod, P., and Pandey, A. (2016). Biological Pretreatment of Lignocellulosic Biomass - an Overview. Bioresour. Tech. 199, 76-82. doi:10. 1016/j.biortech.2015.08.030
Sindhu, R., Kuttiraja, M., Binod, P., Sukumaran, R. K., and Pandey, A. (2014). Bioethanol Production from Dilute Acid Pretreated Indian Bamboo Variety (Dendrocalamus sp.) by Separate Hydrolysis and Fermentation. Ind. Crops Prod. 52, 169-176. doi:10.1016/j.indcrop.2013.10.021

Singh, J., Suhag, M., and Dhaka, A. (2015). Augmented Digestion of Lignocellulose by Steam Explosion, Acid and Alkaline Pretreatment Methods: a Review. Carbohydr. Polym. 117, 624-631. doi:10.1016/j.carbpol.2014.10.012

Sinner, M., Puls, J., and Dietrichs, H. (1979). Carbohydrate Composition of Nut Shells and Some Other Agricultural Residues. Starch/Stärke 31, 267-269. doi:10.1002/star.19790310807

Sørensen, A., Teller, P. J., Hilstrøm, T., and Ahring, B. K. (2008). Hydrolysis of Miscanthus for Bioethanol Production Using Dilute Acid Presoaking Combined with Wet Explosion Pre-treatment and Enzymatic Treatment. J. Bioresour. Technol. 99, 6602-6607.

Stenberg, K., Tengborg, C., Galbe, M., and Zacchi, G. (1998). Optimisation of Steam Pretreatment of SO2-Impregnated Mixed Softwoods for Ethanol Production. J. Chem. Technol. Biotechnol. 71, 299-308. doi:10.1002/(sici) 1097-4660(199804)71:4<299::aid-jctb858>3.0.co;2-z

Stewart, D., Azzini, A., Hall, A. T., and Morrison, I. M. (1997). Sisal Fibres and Their Constituent Non-cellulosic Polymers. J. Ind. Crops 6, 17-26. doi:10.1016/ s0926-6690(96)00172-0

Sun, S., Zhang, L., Liu, F., Fan, X., and Sun, R. C. (2018). One-step Process of Hydrothermal and Alkaline Treatment of Wheat Straw for Improving the Enzymatic Saccharification. Biotechnol. Biofuels 11, 1-10. doi:10.1186/s13068018-1140-x

Sun, S., Sun, S., Cao, X., and Sun, R. (2016). The Role of Pretreatment in Improving the Enzymatic Hydrolysis of Lignocellulosic Materials. Bioresour. Tech. 199, 49-58. doi:10.1016/j.biortech.2015.08.061

Sun, Y., and Cheng, J. (2002). Hydrolysis of Lignocellulosic Materials for Ethanol Production: a Review. Bioresour. Tech. 83, 1-11. doi:10.1016/s0960-8524(01) 00212-7

Świątek, K., Lewandowska, M., Świątek, M., Bednarski, W., and Brzozowski, B. (2014). The Improvement of Enzymatic Hydrolysis Efficiency of Rape Straw and Miscanthus Giganteus Polysaccharides. Bioresour. Technol. 151, 323-331.

Taghizadeh-Alisaraei, A., Abbaszadeh-Mayvan, A., and Hosseini, S. H. (2019). Bioethanol Production from a Mixture of rice hull and orange Peel Wastes. J. Biofuels, 1-5. doi:10.1080/17597269.2019.1655214

Taha, M., Shahsavari, E., Al-Hothaly, K., Mouradov, A., Smith, A. T., Ball, A. S., et al. (2015). Enhanced Biological Straw Saccharification through Coculturing of Lignocellulose-Degrading Microorganisms. J. Appl. Biochem. 175, 3709-3728. doi:10.1007/s12010-015-1539-9

Taherzadeh, M., and Karimi, K. (2008). Pretreatment of Lignocellulosic Wastes to Improve Ethanol and Biogas Production: a Review. Ijms 9, 1621-1651. doi:10. 3390/ijms 9091621

Takano, M., and Hoshino, K. (2018). Bioethanol Production from rice Straw by Simultaneous Saccharification and Fermentation with Statistical Optimized Cellulase Cocktail and Fermenting Fungus. J. Bioresources Bioprocessing 5, 1-12. doi:10.1186/s40643-018-0203-y

Tan, J., Li, Y., Tan, X., Wu, H., Li, H., and Yang, S. (2021). Advances in Pretreatment of Straw Biomass for Sugar Production. Front. Chem. 9. doi:10.3389/fchem.2021.696030

Tarasov, D., Leitch, M., and Fatehi, P. (2018). Lignin-carbohydrate Complexes: Properties, Applications, Analyses, and Methods of Extraction: a Review. Biotechnol. Biofuels 11, 1-28. doi:10.1186/ s13068-018-1262-1

Tiwari, S., Jadhav, S. K., and Tiwari, K. L. (2015). Bioethanol Production from rice Bran with Optimization of Parameters by Bacillus Cereus Strain McR-3. Int. J. Environ. Sci. Technol. 12, 3819-3826. doi:10.1007/s13762014-0746-1

Tufail, T., Saeed, F., Afzaal, M., Ain, H. B. U., Gilani, S. A., Hussain, M., et al. (2021). Wheat Straw: A Natural Remedy against Different Maladies. Food Sci. Nutr. 9, 2335-2344. doi:10.1002/fsn3.2030

Vaid, S., Nargotra, P., and Bajaj, B. K. (2018). Consolidated Bioprocessing for Biofuel-Ethanol Production from pine Needle Biomass. Environ. Prog. Sust. Energ. 37, 546-552. doi:10.1002/ep.12691

Varga, E., Réczey, K., and Zacchi, G. (2003). "(Year). "Optimization of Steam Pretreatment of Corn stover to Enhance Enzymatic Digestibility," in 
Proceedings of the Twenty-Fifth Symposium on Biotechnology for Fuels and Chemicals Held May 4-7 (Breckenridge, CO: Springer), 509-523.

Vats, S., Maurya, D. P., Shaimoon, M., Agarwal, A., and Negi, S. (2013). Development of a Microbial Consortium for Production of Blend of Enzymes for Hydrolysis of Agricultural Wastes into Sugars.

Waghmare, P. R., Khandare, R. V., Jeon, B.-H., and Govindwar, S. P. (2018). Enzymatic Hydrolysis of Biologically Pretreated Sorghum Husk for Bioethanol Production. Biofuel Res. J. 5, 846-853. doi:10.18331/brj2018.5.3.4

Wagner, A., Lackner, N., Mutschlechner, M., Prem, E., Markt, R., and Illmer, P. (2018). Biological Pretreatment Strategies for Second-Generation Lignocellulosic Resources to Enhance Biogas Production. Energies 11, 1797. doi:10.3390/en11071797

Walker, D. J., Gallagher, J., Winters, A., Somani, A., Ravella, S. R., and Bryant, D. N. (2018). Process Optimization of Steam Explosion Parameters on Multiple Lignocellulosic Biomass Using Taguchi Method-A Critical Appraisal. Front. Energ. Res. 6, 46. doi:10.3389/fenrg.2018.00046

Webb, B. D. (1991). "Rice Quality and Grades," in Rice (Springer), 508-538. doi:10. 1007/978-1-4899-3754-4_16

Weil, J., Sarikaya, A., Rau, S.-L., Goetz, J., Ladisch, C. M., Brewer, M., et al. (1997). Pretreatment of Yellow poplar Sawdust by Pressure Cooking in Water. Appl. Biochem. Biotechnol. 68, 21-40. doi:10.1007/bf02785978

Wilkinson, S., Smart, K. A., James, S., and Cook, D. J. (2017). Bioethanol Production from Brewers Spent Grains Using a Fungal Consolidated Bioprocessing (CBP) Approach. Bioenerg. Res. 10, 146-157. doi:10.1007/ s12155-016-9782-7

Wood, I. P., Cao, H. G., Tran, L., Cook, N., Ryden, P., Wilson, D. R., et al. (2016). Comparison of Saccharification and Fermentation of Steam Exploded rice Straw and rice Husk. Biotechnol. Biofuels 9, 193-199. doi:10.1186/s13068-0160599-6

Wu, J., Elliston, A., Le Gall, G., Colquhoun, I. J., Collins, S. R. A., Wood, I. P., et al. (2018). Optimising Conditions for Bioethanol Production from rice Husk and rice Straw: Effects of Pre-treatment on Liquor Composition and Fermentation Inhibitors. Biotechnol. Biofuels 11, 62-13. doi:10.1186/ s13068-018-1062-7

Xiros, C., and Christakopoulos, P. (2009). Enhanced Ethanol Production from brewer's Spent Grain by a Fusarium Oxysporum Consolidated System. Biotechnol. Biofuels 2, 4-12. doi:10.1186/1754-6834-2-4

Yamada, R., Hasunuma, T., and Kondo, A. (2013). Endowing Non-cellulolytic Microorganisms with Cellulolytic Activity Aiming for Consolidated Bioprocessing. Biotechnol. Adv. 31, 754-763. doi:10.1016/j.biotechadv.2013. 02.007

Yoo, C. G., Kuo, M., and Kim, T. H. (2012). Ethanol and Furfural Production from Corn stover Using a Hybrid Fractionation Process with Zinc Chloride and Simultaneous Saccharification and Fermentation (SSF). Process Biochem. 47, 319-326. doi:10.1016/j.procbio.2011.11.018
Yu, Y., and Wu, H. (2010). Significant Differences in the Hydrolysis Behavior of Amorphous and Crystalline Portions within Microcrystalline Cellulose in HotCompressed Water. Ind. Eng. Chem. Res. 49, 3902-3909. doi:10.1021/ie901925g

Zentou, H., Abidin, Z., Yunus, R., Awang Biak, D., and Korelskiy, D. (2019). Overview of Alternative Ethanol Removal Techniques for Enhancing Bioethanol Recovery from Fermentation Broth. Processes 7, 458. doi:10. 3390/pr7070458

Zhang, Y., Ghaly, A., and Li, B. (2012). Physical Properties of Corn Residues. J. Am. J. Biochem. Biotechnol. 8, 44-53.

Zhao, H., Kwak, J. H., Wang, Y., Franz, J. A., White, J. M., and Holladay, J. E. (2006). Effects of Crystallinity on Dilute Acid Hydrolysis of Cellulose by Cellulose ball-milling Study. Energy Fuels 20, 807-811. doi:10.1021/ef050319a

Zhao, J., Zheng, Y., and Li, Y. (2014). Fungal Pretreatment of Yard Trimmings for Enhancement of Methane Yield from Solid-State Anaerobic Digestion. Bioresour. Tech. 156, 176-181. doi:10.1016/j.biortech.2014.01.011

Zhao, L., Cao, G.-L., Wang, A.-J., Ren, H.-Y., Dong, D., Liu, Z.-N., et al. (2012). Fungal Pretreatment of Cornstalk with Phanerochaete Chrysosporium for Enhancing Enzymatic Saccharification and Hydrogen Production. Bioresour. Tech. 114, 365-369. doi:10.1016/j.biortech.2012.03.076

Zheng, Q., Zhou, T., Wang, Y., Cao, X., Wu, S., Zhao, M., et al. (2018). Pretreatment of Wheat Straw Leads to Structural Changes and Improved Enzymatic Hydrolysis. Sci. Rep. 8, 1321-1329. doi:10.1038/s41598-018-19517-5

Zheng, Y., Pan, Z., and Zhang, R. (2009). Overview of Biomass Pretreatment for Cellulosic Ethanol Production. J. Int. J. Agric. Biol. Eng. 2, 51-68.

Zhu, J., Wan, C., and Li, Y. (2010). Enhanced Solid-State Anaerobic Digestion of Corn stover by Alkaline Pretreatment. Bioresour. Tech. 101, 7523-7528. doi:10. 1016/j.biortech.2010.04.060

Conflict of Interest: The author declares that the research was conducted in the absence of any commercial or financial relationships that could be construed as a potential conflict of interest.

Publisher's Note: All claims expressed in this article are solely those of the authors and do not necessarily represent those of their affiliated organizations, or those of the publisher, the editors and the reviewers. Any product that may be evaluated in this article, or claim that may be made by its manufacturer, is not guaranteed or endorsed by the publisher.

Copyright (c) 2022 Adewuyi. This is an open-access article distributed under the terms of the Creative Commons Attribution License (CC BY). The use, distribution or reproduction in other forums is permitted, provided the original author(s) and the copyright owner(s) are credited and that the original publication in this journal is cited, in accordance with accepted academic practice. No use, distribution or reproduction is permitted which does not comply with these terms. 